\title{
Striatal cholinergic interneuron regulation and circuit effects
}

\author{
Sean Austin O. Lim ' ${ }^{1}$ Un Jung Kang ${ }^{2}$ and Daniel S. McGehee ${ }^{1,3 *}$ \\ ${ }^{1}$ Committee on Neurobiology, University of Chicago, Chicago, IL, USA \\ 2 Department of Neurology, Columbia University, New York, NY, USA \\ ${ }^{3}$ Department of Anesthesia and Critical Care, University of Chicago, Chicago, IL, USA
}

\section{Edited by:}

Sukumar Vijayaraghavan, University of Colorado Health Science Center, USA

\section{Reviewed by:}

Maryka Quik, SRI International, USA Teresa Morera-Herreras, University of the Basque Country, Spain

*Correspondence:

Daniel S. McGehee, Department of Anesthesia and Critical Care,

University of Chicago, $5841 \mathrm{~S}$

Maryland Ave., MC4028, Chicago,

IL 60637, USA

e-mail:dmcgehee@uchicago.edu
The striatum plays a central role in motor control and motor learning. Appropriate responses to environmental stimuli, including pursuit of reward or avoidance of aversive experience all require functional striatal circuits. These pathways integrate synaptic inputs from limbic and cortical regions including sensory, motor and motivational information to ultimately connect intention to action. Although many neurotransmitters participate in striatal circuitry, one critically important player is acetylcholine (ACh). Relative to other brain areas, the striatum contains exceptionally high levels of ACh, the enzymes that catalyze its synthesis and breakdown, as well as both nicotinic and muscarinic receptor types that mediate its postsynaptic effects. The principal source of striatal ACh is the cholinergic interneuron (Chl), which comprises only about $1-2 \%$ of all striatal cells yet sends dense arbors of projections throughout the striatum. This review summarizes recent advances in our understanding of the factors affecting the excitability of these neurons through acute effects and long term changes in their synaptic inputs. In addition, we discuss the physiological effects of ACh in the striatum, and how changes in ACh levels may contribute to disease states during striatal dysfunction.

Keywords: acetylcholine, cholinergic interneuron, Parkinson's disease, plasticity, striatum

\section{INTRODUCTION}

The striatum is a subcortical brain region crucial for integrating motivation and action (Da Cunha et al., 2012). Convergence of inputs from motor cortex, thalamus and limbic areas create associations between actions and outcomes that ultimately contribute to survival. The essential nature of the striatum is evidenced by the presence of homologs structures throughout vertebrate evolution over hundreds of millions of years (Stephenson-Jones et al., 2011). Pathological changes in the striatum and associated basal ganglia structures are implicated in a wide variety of neurological and psychiatric disorders that involve the combination of motivation and action, including drug addiction (Koob, 1992), binge-eating (Norgren et al., 2006), obsessive-compulsive disorder (Aouizerate et al., 2004), attention deficit and hyperactivity disorder (Chudasama and Robbins, 2006), Huntington's disease (Cepeda et al., 2007), Parkinson's disease (Albin et al., 1989; Ellens and Leventhal, 2013), and LDOPA induced dyskinesia (Barroso-Chinea and Bezard, 2010). Because so many human pathologies involve striatal dysfunction, a better understanding of neurotransmission in this brain structure will provide insight into the etiology of these conditions, potentially leading to the development of new pharmacotherapies. One neurotransmitter that is highly enriched in the striatum and vitally important for normal function is acetylcholine (ACh). This review will focus on the regulation of striatal $\mathrm{ACh}$ release as well as the functional consequences of cholinergic neurotransmission.
Unlike brain structures that show ordered laminar organization such as the hippocampus or cortex, the striatum is a heterogeneous mix of different cell types. The vast majority of striatal neurons $(\sim 95 \%)$ are the GABA-ergic medium spiny neurons (MSNs), also referred to as spiny projection neurons, which are the principal output cell type. The MSNs that express dopamine (DA) D1 receptors project to and inhibit cells in the internal capsule of the globus pallidus as well as the substantia nigra pars reticulata. These projections are referred to as the direct pathway, or the GO pathway, and activation of this class of cells leads to enhanced locomotion. Another MSN population expresses dopamine D2 receptors, and these projections inhibit cells in the external capsule of the globus pallidus. This is the indirect, or the NO-GO pathway, and activation of this pathway decreases locomotion. Both pathways eventually influence thalamic control of motor cortex to affect motor function. Approximately $6 \%$ of MSNs in the dorsal striatum express both D1 and D2 receptors. These cells produce both GABA and glutamate, allowing them to potentially modulate the basal ganglia network bidirectionally (Perreault et al., 2012). The MSN network of basal ganglia connectivity has provided a model for understanding striatal involvement in motor control (Albin et al., 1989; DeLong, 1990; Kravitz et al., 2010). In addition to the MSNs, approximately $4 \%$ of striatal neurons are GABA-ergic interneurons. These locally projecting inhibitory cells consist of three types: parvalbumin-expressing fast spiking interneurons (FSIs), NPY/SOM/NOS-expressing persistent depolarization low-threshold spiking interneurons, and 
the less understood calretinin-expressing low-threshold calcium spike interneurons (Kawaguchi, 1993). Each of these GABAinterneuron cell types possesses a unique gene expression profile and distinct electrophysiological properties (Tepper et al., 2010).

The remaining cells are the large, aspiny cholinergic interneurons (ChIs) originally described by the anatomist Kölliker in the late 1800 's. Although recent tract tracing and electron microscopy studies report cholinergic projections from the rostral pedunculopontine nucleus into the striatum (Dautan et al., 2014), it is generally accepted that ChIs are the main source of striatal ACh (Woolf and Butcher, 1981). ChIs comprise $\sim 1 \%$ of striatal cells, yet they ramify extensively and send projections widely throughout the striatum: each $\mathrm{ChI}$ is estimated to produce on average 500,000 axonal varicosities (Bolam et al., 1984; Contant et al., 1996). Anatomically, ChIs are easily distinguished from the other striatal cell types due to their large diameter somata (>15 microns). In addition, ChIs display unique electrophysiological characteristics, which include tonic action potential firing at a rate of $3-10 \mathrm{~Hz}$ (Wilson et al., 1990), depolarized resting membrane potential $(\sim-60 \mathrm{mV})$ (Lee et al., 1998), high input resistance $(\sim 200 \mathrm{M} \Omega$ ) (Calabresi et al., 1997$)$, prominent hyperpolarization-activated cation current $\left(\mathrm{I}_{\mathrm{h}}\right)$ (Deng et al., 2007a), and broad action potential duration (Threlfell et al., 2012). The striatum has the highest levels of cholinergic markers in the brain, including ACh, choline acetyltransferase (ChAT), and acetylcholinesterase (AChE) (Macintosh, 1941; Hebb and Silver, 1961; Woolf et al., 1984). Such a high density of cholinergic markers underscores the importance of ACh neurotransmission in the striatum. Therefore, understanding striatal physiology requires careful consideration of the activity of ChIs and the consequences of changes in cholinergic signaling.

Classically, the striatum is subdivided according to synaptic connectivity. For example, the dorsal striatum receives DAergic input primarily from substantia nigra pars compacta (SNc) (Hattori et al., 1991) and sends projections to ventrolateral substantia nigra pars reticulata $(\mathrm{SNr})$ and the globus pallidus. The ventral striatum receives the majority of DA from ventral tegmental area (VTA) projections, and in turn, sends inhibitory projections into the dorsomedial $\mathrm{SNr}$ (Maurin et al., 1999) and globus pallidus. In rodents, the dorsal and ventral striatum subserve different functions: The dorsal striatum is implicated in sensorimotor functions such as serial order learning (Yin, 2010), stimulus-response habit formation (Devan et al., 2011), and performance of learned instrumental tasks (Shiflett et al., 2010), whereas the ventral striatum is important for the reinforcement of appetitive behaviors including drugs of abuse (Robinson and Berridge, 2000) and healthy rewards, such as food intake (Kelley, 2004). Different functional roles are attributed to lateral vs. medial regions of the dorsal striatum. The dorsolateral region, or the "sensorimotor striatum," receives strong motor and premotor cortical inputs, and is therefore particularly important for habit formation (Künzle, 1975; Haber et al., 2000). The dorsomedial striatum, referred to as the "associative striatum," receives inputs from limbic regions as well as prefrontal cortex, and is involved in behavioral flexibility, reward-associated motor learning, and reaction time (Hauber and Schmidt, 1994; Ragozzino, 2003). Gradients of afferent connectivity most likely influence overall striatal output (Voorn et al., 2004), suggesting that these subdivisions are an oversimplification of striatal connectivity and function. Accepting that caveat, the distinctions in function of different striatal regions in the rodent brain provide a framework for ongoing investigations into the neural substrates of relevant behaviors, with an ultimate goal of understanding the functional role of analogous structures in the human brain.

ChIs are believed to be the analogs of tonically active neurons (TANs) identified by in vivo recordings in the putamen of primates. This correlation is based on similarities in ChAT immunoreactivity, electrophysiological, and morphological characteristics (Inokawa et al., 2010). Changes in TAN activity have been linked to motor and reinforcement learning. In classical sensorimotor Pavlovian conditioning, TANs pause activity within a second after presentation of the conditioned stimulus (CS), followed by a transient increase in activity before recovery to baseline firing. This stereotyped neural behavior was described as the "conditioned pause response" (Kimura et al., 1984; Aosaki et al., 1994). This CS-induced change in firing is not dependent on motor activity, as a similar firing profile was observed when the animal was trained to withhold movement after CS presentation in a NO-GO task (Apicella et al., 1991). TANs also pause in response to aversive-CS, but not to neutral stimuli (Ravel et al., 1999). The conditioned pause response is therefore believed to encode salience value to external stimuli. Thus, changes in TAN activity may contribute to associative learning, particularly the relationship between environmental cues and outcomes. The circuitry responsible for the pause response is debated. Some evidence implicates a dependence on SNc DA-ergic tone (Watanabe and Kimura, 1998; Reynolds et al., 2004; Straub et al., 2014), however others have observed a change in TAN firing even in response to aversive stimuli that do not increase DA-ergic firing (Mirenowicz and Schultz, 1996; Ravel et al., 1999). We know that ChIs respond to many neurotransmitters, and this stereotypical pause in activity could be mediated by a variety of inputs. Synchronous changes in afferent activity likely mediate the pause response among multiple ChIs, resulting in a coordinated change in striatal cholinergic tone. Understanding the connectivity and neurotransmission that influences these cells may thus provide insight into learning phenomena.

\section{STRIATAL CHOLINERGIC DYSFUNCTION IN PARKINSON'S DISEASE AND TREATMENT}

The necessity of proper striatal neurotransmission for normal motor function is dramatically and tragically evidenced by the deficits observed in Parkinson's disease (PD). The first medical characterization of PD was published in 1817 (Parkinson, 1817):

\footnotetext{
The first symptoms perceived are, a slight sense of weakness, with a proneness to trembling in some particular part; sometimes in the head, but most commonly in one of the hands and arms... After a few more months the patient is found to be less strict than usual in preserving an upright posture: this being most observable whilst walking.
}

Although this is the first formal description of the disease in Western literature, descriptions of the disease appeared in Eastern 
texts as old as 600 BC (Manyam, 1990; Zhang et al., 2006; Raudino, 2012; Ovallath and Deepa, 2013). Some ancient cultures used treatments derived from herbal preparations that contain anticholinergic compounds with similar pharmacology to some therapies prescribed today (Manyam and Sánchez-Ramos, 1999).

Today, we know that the bradykinesia, resting tremor, rigidity, and difficulty in initiating movement observed in PD arise from deficits in basal ganglia DA transmission. However, it is important to consider the balance between the actions of striatal ACh and DA in the etiology of PD. Previous beliefs held that the two neurotransmitters had opposing actions, which was supported by the partial relief of PD symptoms with administration of anticholinergic compounds. These therapies may restore the balance between the two neurotransmitter systems. Drugs with similar pharmacological properties are still in use, particularly for younger PD patients whose primary symptom is tremor (Hristova and Koller, 2000), but cognitive and autonomic side effects preclude their widespread use. While anticholinergic drugs can improve some symptoms of PD (Whyte et al., 1971; Cantello et al., 1986; Baba et al., 2012), it has also been reported that elevation of ACh by treating patients with acetylcholinesterase inhibitors improves motor symptoms of PD (Chung et al., 2010). Although somewhat contradictory to the anticholinergic drug effects, inhibiting ACh degradation might enhance DA transmission through nicotinic acetylcholine receptors (nAChRs) on DA terminals. Alternatively, this treatment could promote cholinergic receptor desensitization to mimic anticholinergic drug effects. It is important to note that similar cholinesterase treatments have seen no effect on motor symptoms of PD (Poewe et al., 2006). Together, these observations highlight the importance of cholinergic transmission in striatal function under healthy and Parkinsonian conditions.

The physiology of ChIs is dramatically altered in PD. In humans, mutations in leucine-rich repeat kinase 2 (LRRK2) or the gene that encodes $\alpha$-synuclein are both associated with a higher likelihood to develop PD (Simón-Sánchez et al., 2009). These genes are expressed in many basal ganglia cell types and the mechanisms that link these mutations to PD are the subject of ongoing studies (Gasser, 2009). ChIs in both rodents and humans express high levels of LRRK2 (Higashi et al., 2007; West et al., 2014), and abnormal kinase activity may contribute to pathological changes in $\mathrm{ChI}$ physiology. $\alpha$-synuclein inclusions in the somata of ChIs are observed only in late PD but not early PD (Mori et al., 2008), suggesting that Lewy body-related interference of ChI physiology may be observed late in the disease.

In the 6-OHDA lesion model of PD, microdialysis studies have observed that striatal ACh levels are elevated in the DA depleted rat striatum (DeBoer et al., 1993), indicating a dysregulation of ChI excitability. Additionally, functional downregulation of M4Cav2 coupling results in decreased sensitivity to autoinhibitory cholinergic transmission (Ding et al., 2006). Given the therapeutic effects of anticholinergic compounds in PD mentioned above, and the physiological changes in ChIs seen in animal models of the disease, it is evident that ACh is important in PD.

The development of DA replacement therapy to relieve the symptoms of PD in the 1960's revolutionized our understanding of neurotransmission in the dorsal striatum (Goetz, 2011).
Currently, the biochemical precursor to DA, levodopa (L-DOPA) is the most effective clinical treatment for the motor symptoms of PD. L-DOPA crosses the blood brain barrier where it is then converted into DA by aromatic amino acid decarboxylase, thus increasing striatal levels of DA. Although L-DOPA effectively reverses $\mathrm{PD}$ locomotor disability, long-term treatment has its shortcomings, including shortening of the therapeutic window and psychiatric or mood disturbances such as impulse control disorders (Lesser et al., 1979; Voon et al., 2009; Santangelo et al., 2013a,b). Another debilitating side effect is the onset of levodopainduced dyskinesia (LID), which is characterized by dystonia or choreic movements of the limbs, hands, or face. These side effects are potentially more debilitating than PD itself. This condition is highly prevalent, with LID development seen in approximately $40 \%$ of patients after 5 years of treatment, rising to nearly $90 \%$ after 10 years (Ahlskog and Muenter, 2001; Fabbrini et al., 2007). Interestingly, the age of onset of PD is a strong determinant for the development of LID, with earlier onset patients experiencing a more rapid expression of LID symptoms (Kostic et al., 1991; Kumar et al., 2005).

Pathological changes in striatal ACh signaling are related to the expression of LID. The anticholinergic benzatropine decreased dyskinesia in L-DOPA treated human PD patients (Pourcher et al., 1989), however, there are also reports of increased dyskinesia with anticholinergic treatment (Birket-Smith, 1974; Hauser and Olanow, 1993; Linazasoro, 1994). In a study of dyskinetic monkeys, the $\mathrm{mAChR}$ antagonist atropine changed the nature of dyskinesia from dystonia to chorea (Gomez-Mancilla and Bédard, 1993). Although these reports show mixed effects, they do suggest that cholinergic signaling influences the expression of LID. While examining a mouse model of LID, Ding et al. (2011b) observed enhanced levels of phosphorylated extracellular signal-regulated kinase (pERK) specifically in striatal ChIs. Electrophysiological recordings of ChIs revealed higher baseline and dopamine-induced firing rates in LID animals relative to vehicle-treated littermates. The increased ChI excitability and the expression of LID associated behaviors were both inhibited by blockers of MEK/ERK signaling (Ding et al., 2011b). Extending those studies, selective ablation of striatal ChIs decreases LID expression in a unilateral lesion model of PD (Won et al., 2014). Both nicotinic and muscarinic receptors are believed to contribute to LID. Treatment with either nAChR antagonists or nicotine improves abnormal involuntary movements (AIMs) in rodents and primates, which suggests that both drugs are decreasing $\mathrm{nAChR}$ function either through receptor blockade or desensitization (Quik et al., 2007; Bordia et al., 2010; Zhang et al., 2013). Although antimuscarinic drugs have mixed effects in human LID patients as mentioned above, there are reports of decreased LID expression (Pourcher et al., 1989), and a recent study of the Pitx3 mouse model of LID, a muscarinic receptor antagonist decreased behavioral expression of dyskinesia (Ding et al., 2011b). These findings support the conclusion that cholinergic transmission is important for mediating some aspects of LID and that pharmacological modulation of this system may help treat this debilitating condition.

Changes in striatal cholinergic signaling have been observed in patients with other movement disorders and psychiatric illnesses. 
A partial list of these disorders and the nature of the changes in cholinergic activity can be found in Table 1. Considering the importance of striatal ChIs in both normal physiology and in disease, it is clear that this minority of cells plays a major role in the striatum. As such, understanding the nature of efferent and afferent synaptic connectivity of ChIs can provide important insights into striatal physiology.

\section{AFFERENT CONNECTIONS TO Chls}

ChI excitability is affected by a remarkably large number of afferent input types and post-synaptic receptors. A simplified summary of this complex story is presented in Table 2 and Figures 1, 2. This section outlines the current state of our understanding of afferent control of ChIs.

\section{GABA}

ChIs receive a variety of GABA-ergic inputs, both local and extrastriatal in origin. GABA can inhibit cells by activating ionotropic $\mathrm{GABA}_{\mathrm{A}}$ receptors, which increases $\mathrm{Cl}$ - conductance. Of the $\mathrm{GABA}_{\mathrm{A}}$ receptor subunits, the $\alpha 2, \alpha 4, \beta 2 / 3$ subunits are most highly expressed in the striatum (Persohn et al., 1992), and of potential interest, the $\alpha 3$ subunit is expressed only in choline acetyltransferase positive $(\mathrm{ChAT}+)$ cells (RodríguezPallares et al., 2000). Local stimulation produces IPSCs in ChIs, and these events are blocked by bicuculline, indicating that ChIs express functional GABA $\mathrm{G}_{\mathrm{A}}$ receptors (Sato et al., 2014). GABA also activates metabotropic $\mathrm{GABA}_{\mathrm{B}}$ receptors, $\mathrm{G}$-protein coupled receptors (GPCRs) which decrease cell excitation by coupling to the $\mathrm{G}_{\mathrm{i} / \mathrm{o}}$ protein and negatively regulating adenylyl cyclase (AC) (Bettler et al., 2004). Neither immunohistochemical examination of $\mathrm{GABA}_{\mathrm{B}}$ expression in ChIs nor the electrophysiological effects of selective $\mathrm{GABA}_{\mathrm{B}}$ activation on $\mathrm{ChI}$ excitability have been reported. In vivo, microdialysis experiments suggest that tonic activity at $\mathrm{GABA}_{\mathrm{A}}$ receptors regulates $\mathrm{ChI}$ excitability, whereas the $\mathrm{GABA}_{\mathrm{B}}$ receptors do not tonically inhibit ChI activity (DeBoer and Westerink, 1994).

Locally, GABA-ergic MSNs form synaptic connections with ChIs. Substance P-containing inputs are more prevalent than enkephalin-containing terminals, perhaps indicating that D1 MSNs have a more prominent influence over ChI activity compared to D2 MSNs (Martone et al., 1992). MSNs in the intact brain exist in one of two states of excitability, either an up or down state. In the up state, cells rest at a depolarized membrane potential, and are more likely to fire spontaneous action potentials compared to the relatively hyperpolarized down state (Wilson and Groves, 1981). The excitability state of MSNs will thus influence the inhibitory tone on ChIs. In the slice preparation MSNs are silent, and GABA released from these neurons will have minimal impact on ChIs. However, optogenetic activation of MSNs evoked a small amplitude IPSC in $\sim 75 \%$ of ChIs, suggesting that the MSN-ChI connection is highly prevalent (Chuhma et al., 2011). Ultrastructural analysis of TAN connectivity in primates shows that approximately $24 \%$ of all synaptic contacts onto ChAT + cells originate from MSN axon collaterals (Gonzales et al., 2013). In sum, GABA release from MSN onto ChIs is likely a major determinant of excitability of these cells in vivo.
ChIs also receive synaptic inputs from GABA-ergic interneurons. nAChR activation, presumably located on GABA-ergic interneurons, inhibits tonic firing of ChIs (De Rover et al., 2002; Sullivan et al., 2008). Not all GABA-ergic interneurons project to ChIs, however: PV positive FSIs project to MSNs and other interneurons, but do not inhibit ChIs (Szydlowski et al., 2013). Currently, NPY-expressing PLTS GABA-ergic interneurons are the best candidate for inhibition of ChIs, as ultrastructural analysis suggests synaptic connections with choline acetyltransferasepositive striatal neurons (Vuillet et al., 1992). However, there is no direct electrophysiological or functional evidence for this connection. It is unknown if calretinin positive interneurons form connections with ChIs.

Extrastriatal sources of GABA may also inhibit ChIs. Corelease of DA and GABA from nigrostriatal neurons onto MSNs occurs via a VMAT2-dependent vesicular mechanism (Tritsch et al., 2012). Cholinergic activation of nAChRs on those terminals was recently shown to enhance GABAergic inputs to MSNs (Nelson et al., 2014b). We know that DA projections form prominent synaptic contacts onto ChIs (Dimova et al., 1993; Li et al., 2002), and if some of these DA teminals co-release GABA, these inputs could profoundly affect tonic activity of ChIs in vivo. In addition, these projections may also have important implications in $\mathrm{PD}$, as the loss of $\mathrm{SNc}$ projections could decrease this source of GABA-ergic tone onto ChIs, potentially contributing to increases in striatal ACh levels. Other non-dopaminergic projection neurons may contribute to GABA inhibition of ChIs. In addition to DA neurons, the VTA possesses GABA projection neurons that inhibit ventral striatum ChIs (Brown et al., 2012), but whether dorsal striatum ChIs receive GABA input from non-dopaminergic projection neurons in SNc or VTA is not known. Nigrostriatal non-dopaminergic projections have been observed (Gerfen et al., 1987; Rodríguez and González-Hernández, 1999), but the physiological effects of these presumed GABA projections on ChI activity have not been studied. These extrastriatal GABA projections may provide a means to inhibit ChIs that is independent of intrastriatal GABA sources.

\section{GLUTAMATE - IONOTROPIC RECEPTORS}

Glutamatergic innervation of ChIs is predominantly extrastriatal (Künzle, 1975). Glutamate induces rapid depolarization through activation of postsynaptically expressed AMPA, NMDA, or kainate receptors. About half of all ChIs are immunopositive for GluR1, GluR2, and GluR4 subunits (Bernard et al., 1997; Deng et al., 2007b), despite the presence of mRNA of all 4 GluR subunits (Richardson et al., 2000). AMPA receptors expressed on ChIs show rapid deactivation, desensitization, and a relatively high permeability to $\mathrm{Ca}^{2+}$, and these properties differ from the AMPA receptors expressed by MSNs (Götz et al., 1997). mRNA for NR1 and NR2D are present at high levels in ChIs, while expression of NR2A mRNA is contested (Landwehrmeyer et al., 1995; Standaert et al., 1999; Richardson et al., 2000). 90\% of ChIs are immunopositive for the kainate receptors GluR5/6/7 (Chen et al., 1996). In a slice preparation, bath application of an NMDAR positive allosteric modulator increases ChI firing rate (Feng et al., 2014), implying that glutamate tone in the slice preparation contributes to baseline ChI excitability. Considering the expression of these 
Table 1 | Diseases associated with striatal cholinergic dysfunction.

\begin{tabular}{|c|c|c|c|}
\hline Disorder & Nature of change & Species & Citations \\
\hline \multirow[t]{7}{*}{ Parkinson's disease (PD) } & Smokers are less likely to develop PD & Human & $\begin{array}{l}\text { Morens et al., 1995; Allam et al., 2004; } \\
\text { Quik et al., } 2012\end{array}$ \\
\hline & $\begin{array}{l}\downarrow \text { symptoms with anticholinergic } \\
\text { drugs }\end{array}$ & Human (drug trial) & $\begin{array}{l}\text { Katzenschlager et al., 2003; Lanska, 2010; } \\
\text { Fox et al., 2011; Fernandez, } 2012\end{array}$ \\
\hline & $\downarrow$ AChE activity & Human (PET Scan) & Gilman et al., 2010 \\
\hline & $\downarrow \mathrm{nAChR}$ binding & Human (postmortem) & $\begin{array}{l}\text { Rinne et al., 1991; Aubert et al., 1992; } \\
\text { Court et al., 2000; Hellström-Lindahl and } \\
\text { Court, 2000; Bohr et al., 2005; Gotti et al., } \\
\text { 2006a }\end{array}$ \\
\hline & & Monkey (MPTP lesion) & $\begin{array}{l}\text { Kulak et al., 2002; Quik and Mclntosh, } \\
2006\end{array}$ \\
\hline & $\downarrow$ M1 binding & Human (PM) & $\begin{array}{l}\text { Sirviö et al., 1989; Lange et al., 1993; } \\
\text { Piggott et al., } 2003\end{array}$ \\
\hline & Changes in CHRNB3 gene & Human (genotyping) & Bar-Shira et al., 2014 \\
\hline \multirow[t]{4}{*}{ Huntington's disease } & $\downarrow$ in symptoms with AChE inhibitor & Rat (3-NP lesion) & Kumar and Kumar, 2009 \\
\hline & $\downarrow$ ChAT activity & Human & $\begin{array}{l}\text { Bird and Iversen, 1974; Enna et al., 1976a; } \\
\text { Suzuki et al., 2001a }\end{array}$ \\
\hline & $\downarrow$ ChAT mRNA & Mouse (R6/1 model) & Smith et al., 2006 \\
\hline & $\downarrow$ mAChR binding & Human (postmortem) & Hiley and Bird, 1974; Enna et al., 1976a,b \\
\hline \multirow[t]{6}{*}{ Alzheimer's disease } & $\downarrow$ cognitive deficits with AChE & Rat (ketamine induced behavior) & Zugno et al., 2013 \\
\hline & $\downarrow$ AChE levels (in NAc) & Human (PM) & Hammond and Brimijoin, 1988 \\
\hline & $\begin{array}{l}\downarrow \mathrm{nAChR} \text { binding sites in putamen, } \\
\text { but not in caudate }\end{array}$ & Human (postmortem) & Shimohama et al., 1985 \\
\hline & No change in $n A C h R$ binding & Human (postmortem) & Aubert et al., 1992; Gotti et al., 2006a \\
\hline & $\begin{array}{l}\downarrow \text { cognitive deficits with } \alpha 7 \text { or } \alpha 4 \beta 2 \\
\text { agonists }\end{array}$ & Human (drug trial) & Haydar and Dunlop, 2010 \\
\hline & $\uparrow \mathrm{M} 1$ binding & Human (postmortem) & Aubert et al., 1992 \\
\hline \multirow[t]{10}{*}{ Schizophrenia } & $\uparrow$ likelihood to smoke & Human & $\begin{array}{l}\text { Dalack et al., 1998; McEvoy and Allen, } \\
2002\end{array}$ \\
\hline & $\uparrow$ ChAT activity & Human (postmortem) & McGeer and McGeer, 1977 \\
\hline & $\downarrow$ ChAT activity & Human (postmortem) & Bird et al., 1977 \\
\hline & $\downarrow$ ChAT + cells & Human (postmortem) & Holt et al., 1999 \\
\hline & $\begin{array}{l}\downarrow \text { cognitive deficits with nicotine, } \\
\alpha 4 \beta 2 \text { agonist }\end{array}$ & Human (drug trial) & Radek et al., 2010 \\
\hline & $\uparrow \mathrm{nAChR}$ binding & Human (postmortem) & Court et al., 2000 \\
\hline & $\downarrow \mathrm{nAChR}$ binding & Human (postmortem) & Durany et al., 2000 \\
\hline & $\downarrow \mathrm{mAChR}$ binding & Human (SPECT scan) & Raedler et al., 2003 \\
\hline & $\downarrow$ M1 levels & Human (postmortem) & Dean et al., 1996 \\
\hline & Changes in CHNRA7 gene & Human (postmortem, genotyping) & Leonard et al., 2002 \\
\hline \multirow[t]{2}{*}{ Bipolar disorder } & $\downarrow \beta 2 * n A C h R$ binding & Human (PET scan) & Hannestad et al., 2013 \\
\hline & Changes in CHRNA7 gene & Human (genotyping) & Hong et al., 2004; Ancín et al., 2010 \\
\hline \multirow[t]{7}{*}{ Tourette syndrome } & $\downarrow$ ChAT + cells & Human (Postmortem) & Kataoka et al., 2010 \\
\hline & $\downarrow$ tics with cholinesterase inhibitor & Mouse (DOI induced head tics) & Hayslett and Tizabi, 2003 \\
\hline & & Human (drug trial) & Cubo et al., 2008 \\
\hline & $\downarrow$ tics with nicotine & Mouse (DOI induced head tics) & Hayslett and Tizabi, 2003 \\
\hline & & Human (drug trial) & $\begin{array}{l}\text { Shytle et al., 1996; McEvoy and Allen, } \\
2002\end{array}$ \\
\hline & $\downarrow$ tics with nAChR antagonist & Mouse (DOI induced head tics) & Hayslett and Tizabi, 2003 \\
\hline & & Human (drug trial) & Sanberg et al., 1998; Silver et al., 2000 \\
\hline
\end{tabular}


Table 1 | Continued

\begin{tabular}{|c|c|c|c|}
\hline Disorder & Nature of change & Species & Citations \\
\hline \multirow[t]{4}{*}{$\begin{array}{l}\text { Attention Deficit } \\
\text { Hyperactivity Disorder }\end{array}$} & $\begin{array}{l}\text { No change in performance on } \\
\text { attention tasks with } n A C h R \text { agonist }\end{array}$ & Human (drug trial) & Jucaite et al., 2014 \\
\hline & $\begin{array}{l}\uparrow \text { performance on attention tasks with } \\
n A C h R \text { agonist }\end{array}$ & $\begin{array}{l}\text { Rat (MK801 induced attentional } \\
\text { impairment) }\end{array}$ & Rezvani et al., 2012 \\
\hline & Changes in choline transporter gene & Human (genotyping) & English et al., 2009 \\
\hline & Changes in CHRNA4 gene & Human (genotyping) & $\begin{array}{l}\text { Todd et al., 2003; Lee et al., 2008; Guan } \\
\text { et al., 2009; Wallis et al., } 2009\end{array}$ \\
\hline
\end{tabular}

glutamate receptors on ChIs, it is not surprising that application of AMPA, NMDA, or kainate excites ChIs (Calabresi et al., 1998b; Vorobjev et al., 2000; Cepeda et al., 2001). Collectively, the expression of the three functional classes of glutamate receptors support the idea that glutamate is an important determinant of ChI excitability.

Electron microscopy has revealed that glutamate synapses comprise $13 \%$ of total synaptic connections onto ChIs (Gonzales et al., 2013). In the dorsolateral striatum, glutamate is released from cells located in the sensorimotor cortex and the centromedian/parafascicular nucleus of the thalamus, with the vast majority of excitatory projections being thalamic in origin (Berendse and Groenewegen, 1990; Lapper and Bolam, 1992; Thomas et al., 2000; Ding et al., 2010). Glutamatergic inputs, predominantly thalamostriatal projections are likely responsible for synchronous activation of ChIs, which has been suggested to coordinate DA release through activation of $\mathrm{nAChRs}$ on DA terminals (Ding et al., 2010; Threlfell et al., 2012). Another source of glutamate, corelease from SNc dopamine terminals, is a topic of debateOptogenetic activation of SNc dopaminergic axons can produce a small amplitude EPSC in dorsal striatum MSNs (Tritsch et al., 2012). However, using a similar optogenetic approach, others report that glutamate and DA are only coreleased in the ventral, but not dorsal striatum (Stuber et al., 2010). Both of these studies were performed while recording from MSNs, and the electrophysiological significance of SNc-derived glutamate on ChI excitability has not yet been reported. Due to the close proximity between MSNs and ChIs, one would also expect an influence of this source of glutamate on ChIs (Dimova et al., 1993; Li et al., 2002). In this case, the loss of SNc projections in PD may impact the degree to which glutamate modifies ChI activity.

Serotonergic (5-HT) projection neurons from the dorsal raphe nucleus also express glutamate-like immunoreactivity. In culture, 5-HT cells form glutamatergic autapses, indicating that 5-HT projections may functionally co-release glutamate (Nicholas et al., 1992; Johnson and Yee, 1995). The extent to which changes in 5-HT transmission are associated with altered striatal glutamatergic signaling is unknown, but this may contribute to striatal dysfunction in mood disorders. SSRI treatment of depression will prolong the action of synaptically released 5-HT, and may lead to presynaptic inhibition through autoreceptors. This may alter local excitation via co-released glutamate to decrease striatal excitation.

Striatal ChIs also co-release glutamate with ACh (Higley et al., 2011). One isoform of the vesicular glutamate transporter, VGLUT3, is highly expressed in ChIs, and evidence suggests coexpression of this transporter with the vesicular ACh transporter on the same synaptic vesicles. These transporters act synergistically to optimize vesicular loading of ACh and glutamate (Nelson et al., 2014a). Vglut3 knock-out mice have a hypocholinergic striatum, presumably due to a decrease in loading of both glutamate and ACh into vesicles, and also due to less excitatory drive onto synaptically connected ChIs (Gras et al., 2008). The functional consequences of these non-thalamic/non-cortical sources of glutamatergic drive onto ChIs have not been studied in depth.

\section{GLUTAMATE - METABOTROPIC RECEPTORS}

Glutamate also mediates long-term modulation of ChIs via metabotropic glutamate receptors (mGluRs). Excitatory group I mGluRs, which include mGluR1 and mGluR5, are highly expressed on ChIs (Tallaksen-Greene et al., 1998; Bell et al., 2002; Conn et al., 2005), and application of group I agonists induce excitation (Calabresi et al., 1999; Pisani et al., 2001; Berg et al., 2007). This excitation is mediated by a combination of cation currents through $\operatorname{TrpC}$ channels downstream of $\mathrm{G}_{\mathrm{q} \alpha}$, as well as inhibition of the chloride activated $\mathrm{K}^{+}$channel Slo2.1 (Berg et al., 2007). The group II mGluRs, which consist of mGluR2 and mGluR3, decrease excitability by inhibiting AC through activation of $\mathrm{G}_{\mathrm{i} / \mathrm{o} \alpha}$ (Diraddo et al., 2014). mGluR2, mRNA expression on ChIs (Testa et al., 1994; Bell et al., 2002) indicate that agonists of these receptors would theoretically decrease cell excitability. However, group II mGluRs are more involved in the modulation of synaptic inputs onto ChIs, as activation of these receptors results in no change in membrane potential, but decreases the amplitude of both excitatory and inhibitory synaptic inputs onto ChIs (Pisani et al., 2002; Martella et al., 2009). Of the group III mGluRs, only mGluR7 is expressed on ChIs, at a prevalence of $38 \%$ with no expression of mGluR4, 6, or 8 . As with group II mGluRs, group III mGluRs decrease presynaptic release probability by inhibition of the AC pathway (Bell et al., 2002). Although rapid $\mathrm{ChI}$ excitation and inhibition are mediated by ionotropic 
Table 2 | Neurotransmitter systems and their effects on $\mathrm{Chl}$ activity.

\begin{tabular}{|c|c|c|c|}
\hline Neurotransmitter & Source & $\begin{array}{l}\text { Postsynaptic } \\
\text { receptor targets }\end{array}$ & Effect on Chl \\
\hline GABA & $\begin{array}{l}\text { MSN } \\
\text { PLTS interneurons } \\
\text { SNc (?) }\end{array}$ & $\mathrm{GABA}_{\mathrm{A}}$ & GABA $_{A}$ : Inhibition DeBoer and Westerink, 1994 \\
\hline Glutamate & $\begin{array}{l}\text { Intralaminar thalamic nuclei } \\
\text { Sensorimotor cortex } \\
\text { SNc } \\
\text { Raphe nucleus } \\
\text { Chl }\end{array}$ & $\begin{array}{l}\text { GluR1, 2, } 4 \\
\text { GluN1, 2D } \\
\text { Kainate }\end{array}$ & $\begin{array}{l}\text { AMPA, NMDA, Kainate: Excitation Calabresi et al., 1998b; Vorobjev } \\
\text { et al., 2000; Cepeda et al., } 2001 \\
\text { mGluR1,5: Excitation Calabresi et al., 1999; Pisani et al., 2001; Berg } \\
\text { et al., 2007 } \\
\text { mGluR2: Inhibition Martella et al., } 2009 \\
\text { mGluR7: No direct effect Bell et al., } 2002\end{array}$ \\
\hline Dopamine & $\begin{array}{l}\text { SNc } \\
\text { DA-ergic interneurons }\end{array}$ & $\begin{array}{l}\text { D1 (low levels) } \\
\text { D2 } \\
\text { D5 }\end{array}$ & $\begin{array}{l}\text { Increased excitation Aosaki et al., 1998; Centonze et al., 2003; Ding } \\
\text { et al., } 2011 \text { b or } \\
\text { Decreased excitation Deng et al., 2007a; Chuhma et al., } 2014\end{array}$ \\
\hline Histamine & $\begin{array}{l}\text { TMN } \\
\text { Mast cells }\end{array}$ & $\begin{array}{l}\mathrm{H} 1 \\
\mathrm{H} 2 \\
\mathrm{H} 3\end{array}$ & Depolarization and action potential firing Bell et al., 2000 \\
\hline Substance P & D1 MSNs & NK1 & $\begin{array}{l}\text { Depolarization, inward shift in holding current Aosaki and } \\
\text { Kawaguchi, } 1996 \\
\text { Increased ACh release Arenas et al., 1991; Preston et al., } 2000\end{array}$ \\
\hline Enkephalin & D2 MSNs & DOR & Decreased excitation Mulder et al., 1984 \\
\hline Noradrenaline & Locus coeruleus & $\beta 1$ & Depolarization, increased action potential firing Pisani et al., 2003 \\
\hline Adenosine & Degradation of ATP & $\begin{array}{l}A_{1} \\
A_{2 A}\end{array}$ & $\begin{array}{l}\text { Inhibition of ACh release Brown et al., } 1990 \\
\text { Increased ACh release Kurokawa et al., } 1994 \\
\text { No change in ACh release Jin and Fredholm, } 1997\end{array}$ \\
\hline ATP & Synaptic release & $\begin{array}{l}P_{2} X \\
P_{2} Y\end{array}$ & No change in holding current Scheibler et al., 2004 \\
\hline
\end{tabular}

Nitric oxide

NOS+ PLTS interneurons

Depolarization Centonze et al., 2001

Summary of the neurotransmitter systems and other neuromodulators involved in the regulation of Chl activity. "?" denotes potential yet untested source of neurotransmitter release.

receptors, it is important to consider that glutamate can have long term modulatory effects on ChI excitability via mGluR activation.

\section{DOPAMINE}

In addition to GABA and glutamate, there are a number of other neurotransmitter systems that affect ChI activity. Striatal dopamine levels are the highest of any region in the brain and it is a principal determinant of striatal function. The predominant source of dopaminergic innervation of the dorsal striatum is
A9 neurons-neurons which have cell bodies in the SNc and project broadly into the striatum, forming hundreds of thousands of synaptic connections per neuron (Kubota et al., 1987; Chang, 1988; Arbuthnott and Wickens, 2007; Moss and Bolam, 2008; Matsuda et al., 2009; Threlfell and Cragg, 2011). Although synaptic connections to MSNs are well documented, some reports demonstrate dopamine cells synapse onto ChAT positive cells (Hattori et al., 1976) while others report that dopamine modulates ChIs through volume transmission (Lehmann and Langer, 


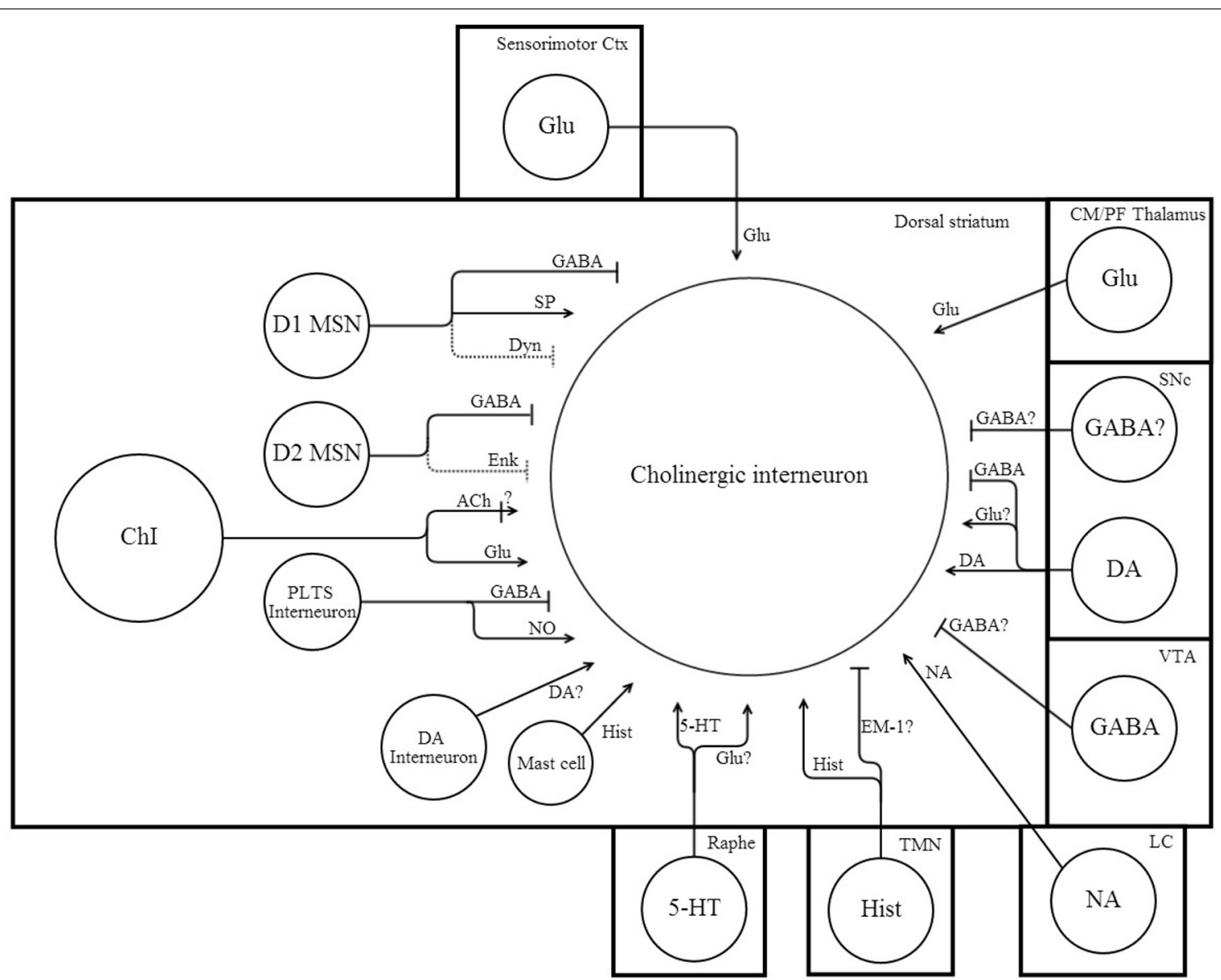

FIGURE 1 | Network connectivity of dorsal striatal cholinergic interneurons. Simplified schematic illustrating some of the afferent synaptic inputs onto Chls. Arrow heads indicate excitation, while perpendicular lines indicate inhibition. Dotted lines indicate a weak synaptic input. "?" denotes uncertain or untested inputs that are expected by either anatomical or physiological results. References that support afferent connections to Chls can be found in the text and Table 2.
1983). These nigral dopaminergic neurons may exist in 4 different activity states. The tonically active state is independent of excitatory drive, as the neurons will fire at a rate of around $3 \mathrm{~Hz}$ in vivo or ex vivo in a slice preparation (Grace and Bunney, 1984; Hyland et al., 2002; Zhou et al., 2006; Ding et al., 2011a; Henny et al., 2012; Guatteo et al., 2013). They also can transition to burst activity with excitatory inputs increasing activity to around $20 \mathrm{~Hz}$ (Grace and Bunney, 1984; Hyland et al., 2002). In addition to these two active states, the cells may exist in one of two silent states, either hyperpolarization below action potential threshold, or depolarization block. Activity of these neurons is crucially important to normal striatal function (Gasser, 2009).

Postsynaptically, the majority of ChIs express D2 and D5 receptors with only about $20 \%$ of the neurons expressing low levels of D1 receptors (Dawson et al., 1988; Bergson et al., 1995; Yan et al., 1997). D2 receptors generally decrease neuronal exitability through activation of $\mathrm{G}_{\mathrm{i} / \mathrm{o} \alpha}$, which also inhibits $\mathrm{AC}$ activity to decrease cAMP levels. D5 receptors are members of the D1 family that activate $\mathrm{AC}$ through $\mathrm{G}_{\mathrm{s}}$ and generally increase excitability (Beaulieu and Gainetdinov, 2011). In the slice preparation, bath application of DA can strongly excite ChIs (Aosaki et al., 1998;
Centonze et al., 2003; Ding et al., 2011b), however others have reported that DA inhibits ChIs by prolonging slow afterhyperpolarization duration (Deng et al., 2007a), and that optogenetic activation of DA terminals induces a pause in ChI firing (Chuhma et al., 2014). It was also reported that amphetamine-induced increases in striatal DA rhas no effect on ACh efflux in vivo (Abercrombie and DeBoer, 1997), implying that, under those conditions, elevated DA does not significantly affect cholinergic tone. Clearly, DA can affect ChI excitability, and the conditions under which DA either excites or inhibits these neurons will require further study.

In addition to this important extrastriatal source of DA, there also exists a small population of striatal DA interneurons in both primates and rodents (Dubach et al., 1987; Cossette et al., 2005; Ibáñez-Sandoval et al., 2010). Interestingly, the number of striatal $\mathrm{TH}+$ cells increases following acute experimental dopamine depletion in both rodents and primates (Tashiro et al., 1989; Betarbet et al., 1997; Smith and Kieval, 2000; Jollivet et al., 2004). This is potentially a compensatory mechanism designed to counteract the loss of DA-ergic innervation from SNc. Strangely, the number of striatal $\mathrm{TH}+$ cells is decreased in humans with $\mathrm{PD}$ 


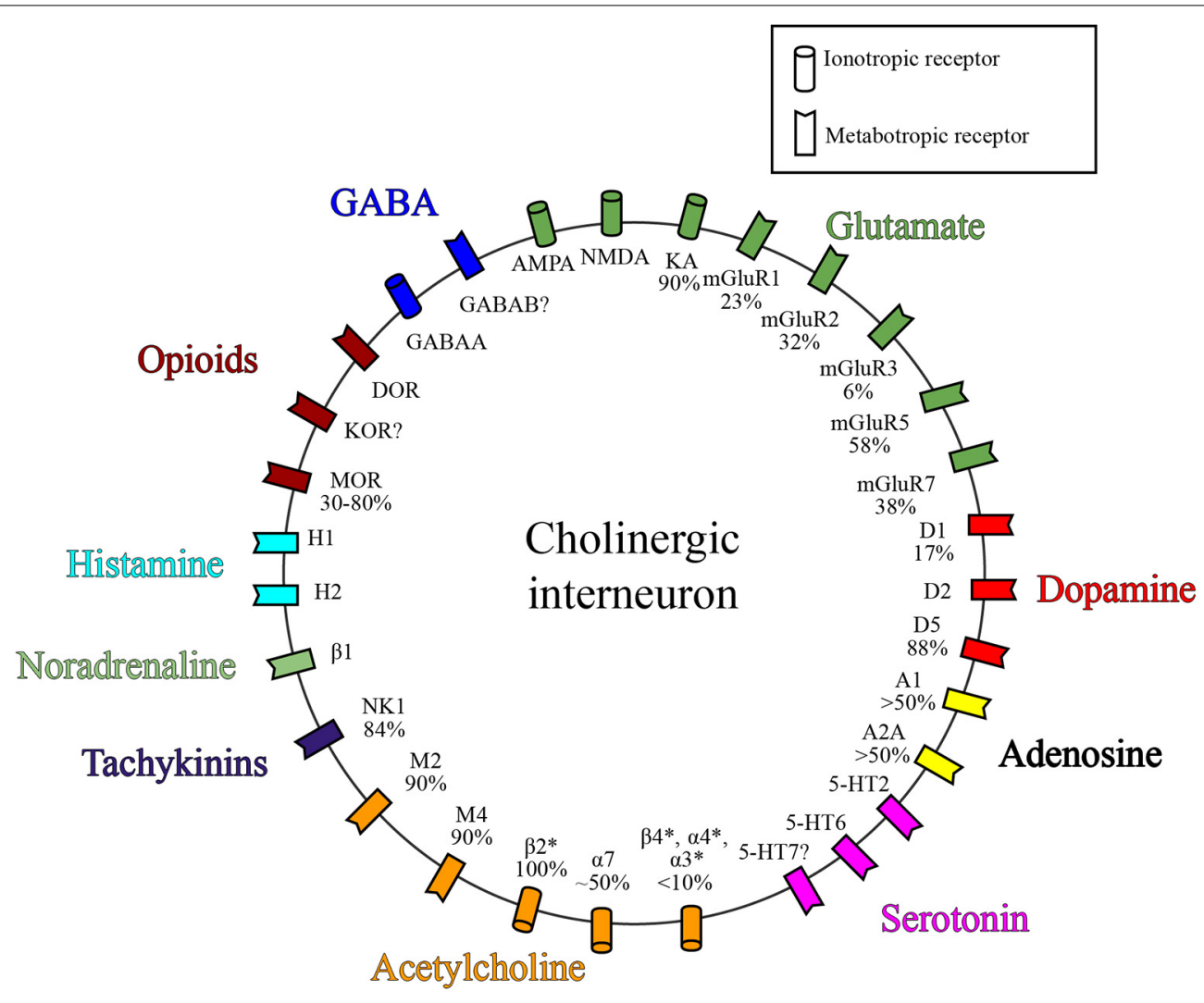

FIGURE 2 | Receptor expression on Chls. Simplified diagram depicting a subset of known receptor classes expressed on Chls grouped by neurotransmitter. Values represent percent of Chls that express the given receptor. References for receptor expression by Chls can be found in the text and Table 2 .

(Huot et al., 2007), highlighting one difference between experimentally induced PD and the actual pathogenesis of the disease in humans. These DA interneurons form inhibitory GABA-ergic synapses with MSNs (Ibáñez-Sandoval et al., 2010). Whether or not these $\mathrm{TH}+$ interneurons make DA-ergic and/or GABA-ergic synaptic contacts with ChIs is yet to be determined. Another interesting question to address would be whether or not these $\mathrm{TH}+$ interneurons undergo changes in physiology that serve in a homeostatic role in the Parkinsonian striatum. Independent of changes in cell numbers outlined above, increased excitability following DA depletion may counteract low levels of striatal DA to help maintain striatal function. This small minority of striatal cells remains an interesting focus for future investigations.

\section{ACETYLCHOLINE}

ChIs receive synaptic inputs from other ChIs. Both nAChRs and $\mathrm{mAChRs}$ are expressed at various levels on ChIs. With respect to $\mathrm{nAChR}$ expression, in situ hybridization has shown that all ChIs express mRNA for $\beta 2$ subunits, about half express $\alpha 7$ mRNA, while other subunit mRNAs are expressed at low levels (Azam et al., 2003). In support of the idea that ChIs express nAChRs, nicotine application to a slice preparation induces ACh release (Sandor et al., 1991). Interestingly, that effect was only seen in slices from animals that had undergone dopamine depletion with 6-OHDA treatment or in the presence of the D2 receptor antagonist sulpiride. These data suggest that resolving the nAChR-mediated ACh release requires elimination of D2 receptor mediated inhibition (Sandor et al., 1991).

The mAChR component of ACh modulation is through activation of the $\mathrm{G}_{\mathrm{i} / \mathrm{o}}$ coupled M2 and M4 receptors (Weiner et al., 1990; Smiley et al., 1999; Ding et al., 2006), thus acting as an autoinhibitory clamp to prevent excessive ACh release. No co-expression of M1 and ChAT is observed in the striatum (Dawson et al., 1990; Alcantara et al., 2001).

Synchronized activity in ChIs is observed following presentation of behaviorally salient stimuli (Apicella et al., 1997; Ravel et al., 1999). Although this synchronous firing has been linked to coordinated thalamostriatal inputs (Ding et al., 2010), ChI projections to other ChIs may also contribute to this synchrony through positive feedback control to coordinate strong increases in ACh. Whether or not nAChR mediated transmission contributes to ChI-ChI signaling has yet to be reported.

\section{SEROTONIN}

Serotonin is a major determinant of ChI excitability. 5-HT-ergic projections originate from the raphe nucleus in the hind brain. These cells fire tonically at a rate of about $1-2 \mathrm{~Hz}$ (Innis and Aghajanian, 1987; Sprouse et al., 1989; Haj-Dahmane et al., 1991), releasing 5-HT into many brain areas including the striatum. 5-HT has an overall direct excitatory effect on ChIs, increasing action potential firing and membrane depolarization (Blomeley and Bracci, 2005; Bonsi et al., 2007). Activation of the $\mathrm{G}_{\mathrm{q}}$-coupled 
5-HT2 receptors increases excitability due to a decrease in the amplitude of both the slow and medium afterhyperpolarization (AHP) (Blomeley and Bracci, 2005). It has not been examined if 5-HT receptor classes 1A, 3, or 4 are expressed on ChIs, however selective agonists of these receptor classes do not induce changes in ChI excitability (Blomeley and Bracci, 2005). 5-HT6 activation excites ChIs (Bonsi et al., 2007). The contribution of the 5-HT7 receptor to excitation is debated, as Blomeley and Bracci (2005) reported no effect, while Bonsi et al. (2007) observed depolarization.

\section{HISTAMINE}

Histamine (HA) is a neurotransmitter that was first identified as a peripheral vasodilator with an effect on respiratory patterns and muscle tone (Dale and Laidlaw, 1910). Originally described in the brain in 1984, HA immunoreactive fibers were found to project widely throughout the brain including the striatum (Haas et al., 2008). HA-ergic cell bodies reside only in a small region of the posterior hypothalamus, the tuberomamillary nucleus (Panula et al., 1984; Blandina et al., 2012). Histamine is also produced by mast cells (Schwartz et al., 1986).

HA can act on 4 different types of G-protein coupled receptors, H1 through H4 (Parsons and Ganellin, 2006). These receptors are widely expressed, but only $\mathrm{H} 1, \mathrm{H} 2$, and $\mathrm{H} 3$ are highly expressed in the striatum, with $\mathrm{H} 1$ and $\mathrm{H} 2$ expressed on ChIs, and the autoreceptor $\mathrm{H} 3$ being expressed presynaptically on HA-ergic terminals. $\mathrm{H} 1$ and $\mathrm{H} 2$ are excitatory, coupling to $\mathrm{G}_{\mathrm{q}}$ and $\mathrm{G}_{\mathrm{s}}$ respectively, while the inhibitory $\mathrm{H} 3$ receptor is coupled with $\mathrm{G}_{\mathrm{i}}$ (Timmerman, 1989; Haas et al., 2008). HA application has the net result of depolarization of ChIs, presumably acting through by $\mathrm{H} 1$ receptors (Bell et al., 2000). In the ventral striatum, ACh overflow is increased following $\mathrm{H} 1$ activation, while blockade of $\mathrm{H} 2$ increases ACh overflow, presumably through activation of $\mathrm{H} 2$ on GABA interneurons (Prast et al., 1999b). The same group found an increase in ACh overflow with concurrent $\mathrm{H} 3$ activation, an effect mediated by presynaptically expressed GABA interneurons (Prast et al., 1999a).

\section{OPIOIDS}

ChIs are also sensitive to opioidergic modulation. $\delta, \kappa$, and $\mu$ opioid receptors (DOR, KOR, and MOR, respectively) are the three major classes of opioid receptors in mammals. These receptors inhibit cell activity through coupling with $\mathrm{G}_{\mathrm{i} / \mathrm{o}}$ proteins (Mansour et al., 1994; Tso and Wong, 2003), and are activated endogenously by a number of tightly regulated peptides. The endogenous opioid enkephalin activates DORs, and is produced by D2 expressing indirect pathway MSNs. mRNA for DORs is expressed in striatal ChIs (Le Moine et al., 1994), and activation of these receptors decreases ACh release (Mulder et al., 1984). The low number of synaptic connections between enkephalinergic cells and ChAT positive cells (Martone et al., 1992) suggests that enkephalin may only minimally inhibit ChI activity endogenously, but this does not preclude the possibility of volume transmission. Systematic investigation of endogenous DOR effects on ChI excitability has not been reported.

KOR is another major class of opioid receptors in the striatum. The endogenous opioid dynorphin is produced by D1 expressing direct pathway MSNs, and activates KORs. Like DORs, KORs are widely expressed in the striatum (Fallon and Leslie, 1986; Mansour et al., 1994). Compared to the DOR or MOR, the KOR receptor can be associated with $\mathrm{G}_{\mathrm{i} / \mathrm{o}}$ as well as $\mathrm{G}_{\mathrm{s}}$. This bipolar effect of KOR activation is concentration dependent. At very low, subnanomolar concentrations of agonist, KOR preferably couples to $G_{s}$ (Crain and Shen, 1996), but increasing the concentration results in the activation of signaling cascades downstream of $\mathrm{G}_{\mathrm{i} / \mathrm{o}}$ (Gross et al., 1990; Claye et al., 1996). Thus, depending on the level of striatal dynorphin, ChIs may either increase or decrease their excitability. KOR activation decreases ACh release in the striatum (Mulder et al., 1991; Schoffelmeer et al., 1997), however, different studies showed no effect of KOR activation on ACh release (Arenas et al., 1990; Jackisch et al., 1993). These apparently contradictory findings could result from the biphasic dose-dependent intracellular coupling of the KOR. It is also possible that the KOR effects on ACh release occur through indirect modulation, as there has not been a direct demonstration of co-localization of KOR with ChAT expression in striatum, nor is there direct electrophysiological evidence of KOR expression on ChIs.

The MOR is also coexpressed on ChAT positive striatal cells, however with tremendous diurnal variation, fluctuating from $30 \%$ coexpression in the daytime to a peak of $80 \%$ coexpression in the afternoon (Jabourian et al., 2005). Activation of MOR by exogenous DAMGO decreases ChI firing (Ponterio et al., 2013). MOR-inhibition of $\mathrm{ACh}$ release lowers the DA release probability in striatum by limiting activation of presynaptic nAChRs (Britt and McGehee, 2008). Endomorphin-1 (EM-1), an endogenous agonist at the MOR, shows only weak immunoreactivity in the striatum. EM-1 may be co-released by histaminergic neurons, as the EM-1 immunoreactivity signal is very prominent in the posterior hypothalamus (Martin-Schild et al., 1999). In addition, some endogenous agonists have overlapping affinity for different opioid receptor classes, such as Leu-enkephalin, which activates both DORs, and MORs at physiological concentrations (Jabourian et al., 2005).

\section{TACHYKININS}

Tachykinins are another class of neuropeptides expressed in the striatum. In addition to producing GABA and dynorphin, D1-expressing MSNs also express the tachykinin Substance P Terminals that contain Substance P. form synaptic connections with ChIs. Substance P. is a potent activator of NK1 receptors, which are expressed by ChIs (Bolam et al., 1986; Richardson et al., 2000). Activation of NK1 results in excitation (Aosaki and Kawaguchi, 1996) and increased ACh release (Arenas et al., 1991; Preston et al., 2000).

\section{EFFERENT CONNECTIONS OF Chls}

Even though the ChIs make up a small fraction of cells in the striatum, they possess a large synaptic arbor and thus send ACh projections broadly throughout the striatum. As such, changes in ChI physiology influence a multitude of postsynaptic targets by activation of nicotinic and muscarinic ACh receptors. This section addresses the effects of ACh neurotransmission. 


\section{NICOTINIC ACETYLCHOLINE RECEPTORS}

Nicotinic acetylcholine receptors (nAChRs) are ligand-gated, pentameric ion channels that are activated by endogenous $\mathrm{ACh}$, exogenous nicotine, or other ligands. nAChRs can be expressed both pre and postsynaptically, where they induce depolarization and increase excitability. Presynaptic nAChRs enhance release of several different neurotransmitter types (MacDermott et al., 1999). The subunits that are assembled into neuronal nAChRs include $\alpha 2-\alpha 10$ and $\beta 2-\beta 4$ (Patrick et al., 1993; McGehee and Role, 1995; Dani, 2001). They can be composed of homomeric or heteromeric subunit combinations, which determine characteristic pharmacological and biophysical properties of the receptor (Fenster et al., 1997; Gotti et al., 2006b). In the striatum, the most common nAChR subunits are the $\alpha 4, \alpha 6, \alpha 7, \beta 2$, and $\beta 3$, although other subunits are present at lower levels (Quik et al., 2007). Generally, nAChR activation induces rapid depolarization, but $\mathrm{Ca}^{2+}$ entry, particularly through homomeric $\alpha 7$ nAChRs can lead to rapid changes in neurotransmitter release or long term changes in cellular function through activation of $\mathrm{Ca}^{2+}$ dependent intracellular cascades, such as altered transcription through pCREB activation (Mulle et al., 1992; Chang and Berg, 2001; Hu et al., 2002; Wu et al., 2009; Del Barrio et al., 2011).

\section{MUSCARINIC ACETYLCHOLINE RECEPTORS}

In comparison to the rapid, excitatory effect of nAChR activation, mAChR activation serves a more long-term modulatory role. Activation of $\mathrm{mAChRs}$ can either increase or decrease cell excitability. A total of 5 subtypes of $\mathrm{mAChRs}$ have been isolated and cloned, but they are generally divided into 2 classes based on differences in their intracellular signaling cascades. The excitatory mAChRs, consisting of $\mathrm{M} 1, \mathrm{M} 3$, and $\mathrm{M} 5$, couple to $\mathrm{G}_{\mathrm{q} / 11}$ and induce activation of the phospholipase $\mathrm{C}$ pathway (Lin et al., 2004). The inhibitory receptors, $\mathrm{M} 2$, and $\mathrm{M} 4$, couple to $\mathrm{G}_{\mathrm{i} / \mathrm{o}}$ proteins and decrease activity of adenylyl cyclase (Wess, 1996). All $5 \mathrm{mAChRs}$ are expressed in the striatum (Yan et al., 2001), however M1 and M4 are more heavily expressed than other isoforms, with a small presence of M2 and very low levels of M3 and M5 expression (Yasuda et al., 1993). Muscarinic receptors are not limited to somatic expression, as terminal expression of mAChRs serves to modulate neurotransmitter release probability. Expression of M2 receptors on ChI terminals serves an autoinhibitory role (Hersch et al., 1994). Additionally, neurotransmitter release at incoming afferents can be sensitive to mAChR modulation, as these $\mathrm{mAChRs}$ can receive synaptic inputs from ChIs. Because $\mathrm{mAChR}$ activation can either increase or decrease cell excitability, the net effect of ACh release depends on the patterns of postsynaptic mAChR expression. For each major striatal postsynaptic target, both the nicotinic and muscarinic effects on neuronal excitability will be addressed.

\section{MEDIUM SPINY NEURONS}

GABA-ergic MSN projection neurons are the sole output of the striatum. Direct activation of AChRs on MSNs therefore represent a direct effect of ACh on striatal output. MSNs are generally believed to lack nAChRs (Matsubayashi et al., 2001; Luo et al., 2013), although Liu et al. (2007) reports that direct activation of nAChRs on MSNs by nicotine induces depolarization. This direct
nAChR modulation of MSN activity has not been explored in depth, as the evidence that MSNs express nAChRs is quite limited. Interestingly, lesion studies indicate that only about $20 \%$ of $\alpha 4 \beta 2$ nAChRs are expressed on DA terminals (Quik and Wonnacott, 2011). Thus, the contribution of these receptors to striatal circuitry likey involves expression on GABAergic interneurons and presynaptic projections from a range of cell types. Resolving the complete physiological role of striatal $\alpha 4 \beta 2$ receptors is a topic of ongoing investigations.

The majority of studies of ACh-mediated modulation of MSNs focuses on $\mathrm{mAChR}$ activation. Bath application of the mAChR agonist carbachol increases MSN excitation in the absence of synaptic input, both in a slice preparation and in dissociated cell culture (Hsu et al., 1996; Galarraga et al., 1999). Two mechanisms have been proposed to explain this excitation. One involves an M1 mediated decrease in the inhibitory KCNQ potassium (Kv7) current (Shen et al., 2005), while the other an M1 mediated inhibition of $\mathrm{Ca}^{2+}$ entry through $\mathrm{N}$ and $\mathrm{P} / \mathrm{Q}$ type channels, which in turn decreases the duration of the AHP (Pérez-Garci et al., 2003; Perez-Rosello et al., 2005). Neither of these studies differentiates between the direct and indirect pathway MSNs, and the mechanisms could differ between these cell types. Inhibitory M4 receptors are expressed on a subpopulation of MSNs (Bernard et al., 1992), and functional electrophysiological evidence suggests that M4 decreases $\mathrm{Ca}^{2+}$ influx to decrease excitability (Howe and Surmeier, 1995). Direct pathway MSNs express both M1 and M4, while indirect pathway MSNs express M1. Less than half of indirect pathway MSNs express M4 (Bernard et al., 1992; Yan et al., 2001). Both classes of MSNs would be excited with M1 activation, but the differential expression pattern of the inhibitory M4 could mean that ACh influences the two classes of MSNs in opposing directions.

\section{GABA-ERGIC INTERNEURONS}

In addition to directly acting on MSNs, ACh can also modify striatal output through receptors on GABA interneurons that project to MSNs. Optogenetic activation of cholinergic cells produced IPSCs and IPSPs in MSNs that were inhibited by nAChR blockade. This microcircuit is believed to be a disynaptic connection, consisting of nAChR-expressing GABA interneurons that are activated by $\mathrm{ACh}$, which then release GABA onto MSNs (English et al., 2011). The GABA interneurons that contribute to this inhibition of MSNs are likely the parvalbumin-expressing FSIs (Chang and Kita, 1992) and/or the NPY-expressing PLTS interneurons (English et al., 2011). However, English and coworkers did not observe an involvement of FSIs in the ChI-MSN interaction. Consistent with $\mathrm{nAChR}$ activation leading to elevated striatal GABA, inhibition of $\alpha 7$ receptors resulted in a decrease in striatal GABA in awake behaving animals (Beggiato et al., 2013), while activation of $\alpha 7 \mathrm{nAChRs}$ increases GABA levels (Campos et al., 2010).

Muscarinic receptor activation of GABA interneurons that project to MSNs can influence striatal output. Subcellular localization of the M2 receptor has been demonstrated in the NPY+ PLTS interneurons (Bernard et al., 1998). Consistent with this result, ACh decreases striatal GABA release (Marchi et al., 1990). More specifically, this is mediated by an inhibitory $\mathrm{mAChR}$, as 
muscarine decreases GABA release onto MSNs (Sugita et al., 1991). Thus far, there are no reports of M1 receptor expression on GABA interneurons, but it is possible that M1-mediated enhancement of GABA output from one of the other interneuron subtypes neurons could contribute to striatal circuitry.

\section{GLUTAMATERGIC TERMINALS}

Glutamatergic inputs into the dorsal striatum originate primarily from the intralaminar nuclei of the thalamus and from the sensorimotor cortex, with a small amount of glutamate co-released from other terminals as well (Higley et al., 2011). nAChR expression on glutamatergic terminals provides a mechanism for cholinergic enhancement of excitatory drive onto MSNs. Increased glutamate release through activation of presynaptic nAChRs has been observed in brain regions such as the hippocampus, medial habenula, olfactory bulb and human neocortex (McGehee et al., 1995; Gray et al., 1996; Fisher and Dani, 2000; Girod et al., 2000; Marchi et al., 2002). Glutamate release probability is also modulated by nAChRs in the striatum (Kaiser and Wonnacott, 2000). In vivo microdialysis studies demonstrate that $\alpha 7 \mathrm{nAChR}$ activation in striatum increases glutamate release (Campos et al., 2010). $\alpha 7 \mathrm{nAChR}$ antagonism decreases glutamate release (Carpenedo et al., 2001), indicating that baseline ACh levels contribute to glutamatergic tone. Because the homomeric $\alpha 7$ subtype is highly $\mathrm{Ca}^{2+}$ permeable compared to other nAChRs stoichiometries, $\mathrm{Ca}^{2+}$ entry through these receptors may lead directly to enhanced neurotransmitter release (Gray et al., 1996). Activation of the $\alpha 4 \beta 2 *$ subtype also increases glutamate release onto MSNs (Xiao et al., 2009). As glutamatergic inputs originate from various neuronal types and brain regions, differential expression of $\mathrm{nAChR}$ stoichiometries may allow ChIs to amplify glutamate inputs differentially.

In contrast, activation of mAChRs negatively modulates striatal glutamate release. In field potential recordings, a mAChR agonist suppressed corticostriatal glutamatergic transmission (Malenka and Kocsis, 1988). Increasing mAChR signaling either by increasing $\mathrm{ChI}$ firing rates, or exogenous agonist application decreases excitatory drive onto MSNs (Calabresi et al., 1998a; Pakhotin and Bracci, 2007; Pancani et al., 2014). Muscarinic modulation of glutamatergic terminals occurs through M2 or M4 receptor activation, as mRNA and protein levels for both mAChRs are observed at high levels in striatal somata as well as terminals (Levey et al., 1991; Hersch et al., 1994). M2 or, interestingly enough, M3 activation results in paired pulse facilitation, indicating that $\mathrm{mAChR}$ activation decreases glutamate release probability (Hernández-Echeagaray et al., 1998; Ding et al., 2010). The change in release probability is observed in both corticostriatal afferents and thalamostriatal afferents, and when recording from both direct and indirect MSNs, indicating that regardless of the origin of the terminal or the post-synaptic target, release probability at glutamatergic terminals is decreased with $\mathrm{mAChR}$ activation (Ding et al., 2010). In agreement with these observations, intrastriatal injections of an M2-selective antagonist increases glutamate overflow (Smolders et al., 1997), providing evidence that tonic levels of $\mathrm{ACh}$ contribute to striatal glutamate tone. Additionally, glutamate release is downregulated via $\mathrm{mAChR}$ activation (Dodt and Misgeld, 1986). ChIs are thus in a position to regulate excitatory inputs to $\mathrm{MSN}$, both rapidly by acting on nAChRs, and more slowly and persistently via mAChR activation.

\section{DOPAMINERGIC TERMINALS}

ACh profoundly modulates DA release in the striatum. In a slice preparation, optogenetic activation of ChIs increases evoked DA release. The quantity of DA released is dependent on frequency of stimulation, and requires synchronous ChI cell activation as well as activation of $\beta 2$-containing $\mathrm{nAChRs}$ expressed on dopaminergic terminals (Cachope et al., 2012; Threlfell et al., 2012). Although the physiological conditions that coordinate synchronous firing of large numbers of ChIs are unknown, cross-talk between ChIs may facilitate simultaneous firing of these neurons to enhance DA release.

Dopaminergic terminals express $\alpha 4$ and $\beta 2$ subunits at high levels, along with $\alpha 5, \alpha 6, \alpha 7$, and $\beta 3$ subunits at variable levels (Le Novère et al., 1996; Sharples et al., 2000; Jones et al., 2001; Klink et al., 2001; Quik et al., 2003; Grady et al., 2007; Keath et al., 2007). Nicotinic agonists increase the efflux of DA in striatal tissue, as measured by microdialysis (Puttfarcken et al., 2000; Campos et al., 2010), and as expected, nAChR antagonists decrease DA efflux by interfering with the effects of local ACh activation of presynaptic nAChRs on DA terminals (Wonnacott et al., 2000; Grady et al., 2007). There is evidence that enhancement of DA release by exogenous activation of $n A C h R s$ requires glutamatergic signaling (Garcia-Munoz et al., 1996; Wonnacott et al., 2000), but enhancement of DA release by coordinated ACh release from ChIs is not dependent upon glutamate transmission (Threlfell et al., 2012). Additionally, striatal dopaminergic terminals also corelease GABA. In a recent study, optogenetic activation of ChIs produces a GABAA receptor mediated synaptic response in MSNs. Pharmacological blockade of $\alpha 4 \mathrm{nAChRs}$ inhibits this GABA current, suggesting that striatal nAChRs regulate GABA levels via modulation of release probability from DA terminals (Nelson et al., 2014b).

The expression of nAChRs on DA terminals not only enhances DA transmission, chronic agonist exposure, such as that achieved in tobacco users can shift DA release probability to suppress release during low frequency activity, but maintain or enhance release during burst firing (Zhou et al., 2001; Rice and Cragg, 2004; Zhang and Sulzer, 2004). These observations were obtained using high resolution fast-scan cylclic voltammetry to assess extracellular DA levels, and they suggest that nicotine may enhance the impact of high frequency DA neuron activity to effectively increase the salience of environmental stimuli. Recent in vivo investigations suggest that a chronic nicotine exposure model, which mimics the daily pattern of nicotine exposure by smokers ( 2 weeks via drinking water), results in a downregulation of electrically stimulated DA release due to persistent desensitization of nAChRs on DA terminals (Koranda et al., 2014). This observation extends the results seen in other preparations including brain slices and non-human primates (Perez et al., 2012, 2013; Exley et al., 2013). Together, these findings have led to the intriguing speculation that the reported protective effects of smoking against PD may result from an adaptation in striatal 
circuitry to lower DA levels, thus delaying the onset of symptoms (Koranda et al., 2014).

Exogenous nicotine affects striatal dopamine in interesting and sometime counterintuitive ways, as the interplay between nAChR activation and desensitization can lead to contradictory effects. In contrast, endogenous ACh from ChIs is rapidly degraded by acetylcholinesterase, which is expressed at remarkably high levels in striatum. As alluded to above, synchronous $\mathrm{ChI}$ activation can have profound effects on DA release in striatum, through the coordinated activation of presynaptic nAChRs on DA terminals (Threlfell et al., 2012). This study from the Cragg laboratory used optogenetic stimulation to coordinate $\mathrm{ChI}$ activity selectively to demonstrate this phenomenon. This is relevant to endogenous activation of ChIs, as synchronous stimulation of these neurons has been reported through coordination of thalamostriatal inputs in response to salient environmental stimuli (Ding et al., 2010; Threlfell et al., 2012).

While mAChRs are also involved in modulation of DA release, the identity of mAChRs expressed by $\mathrm{SNc} \mathrm{DA}$ cells is unclear, as some observe M2, M4, and M5 (Vilaró et al., 1990; Levey et al., 1991), while others report expression of only M5 receptors (Weiner et al., 1990). Agreement on M5 receptor expression suggests that dopaminergic terminals in the striatum express this $\mathrm{mAChR}$ subtype. Electrophysiological evidence supports this, as M5 KO mice show reduced oxotremorine enhancement of potassium-stimulated dopamine release (Zhang et al., 2002). M2 receptors are also involved in tonic DA release, as intrastriatal administration of an M2 antagonist dramatically increases DA levels in freely moving rats (Smolders et al., 1997). Non-selective activation of striatal mAChRs with oxotremorine increases DA release (Lehmann and Langer, 1982; Threlfell et al., 2010), suggesting that M5 activation plays a stronger role in the modulation of DA terminals.

\section{PLASTICITY OF THE EXCITATORY INPUTS TO CHOLINERGIC INTERNEURONS}

Activity-dependent modification of synaptic connections is believed to be an important cellular substrate for learning and memory. As the dorsal striatum is believed to be an important site of action for habit formation and motor learning, it is likely that synaptic plasticity contributes to that learning. Considerable effort has focused on understanding the plasticity of the excitatory inputs to MSNs (Calabresi et al., 1996; Mahon et al., 2004; Surmeier et al., 2007), however, LTP/LTD in ChIs has not been explored extensively. Recording in tissue slices from dorsal striatum, Suzuki et al. (2001b) demonstrated LTP in ChIs following a $1 \mathrm{~s}, 100 \mathrm{~Hz}$ train stimulation of the corpus callosum. This LTP was dependent on $\mathrm{Ca}^{2+}$ entry, as intrapipette BAPTA blocked LTP induction. The source of $\mathrm{Ca}^{2+}$ entry in these studies was not from NMDA receptors, as NMDA blockers had no effect on LTP induction. They also found this LTP to be D5 receptor dependent, as pharmacological blockade of D1/D5 receptors prevents the long term maintenance of enhanced synaptic strength, whereas D2 receptor blockade did not affect LTP induction (Suzuki et al., 2001b). Bonsi and co-workers observed a similar LTP (using three $1 \mathrm{~s}, 100 \mathrm{~Hz}$ trains), however they attribute LTP at these synapses to calcium entry via L-type HVA channels, and not to $\mathrm{Ca}^{2+}$ permeable AMPA receptors or NMDA receptors (Bonsi et al., 2004). Using the same HFS stimulation paradigm as Bonsi et al, Picconi and coworkers demonstrate that plasticity of ChIs is not observed in the R6/2 mouse model of Huntington's disease (Picconi et al., 2006). It is not clear why a Huntington's disease model should lack plasticity at these synapses, which highlights the need for better understanding of the underlying mechanisms and functional significance of synaptic plasticity of the inputs to striatal ChIs.

Spike-timing dependent plasticity (STDP) is another experimental paradigm used to induce plasticity. In accordance with Hebbian theory, changing the time between presynaptic activation and postsynaptic depolarization can elicit either a strengthening, weakening, or no change in synaptic strength. First discovered in the cortex, examples of STDP have been observed in other parts of the nervous system including the hippocampus, striatum neuromuscular junction, and cerebellum (Linden et al., 1991; Markram et al., 1997; Wan and Poo, 1999; Nishiyama et al., 2000; Plotkin et al., 2013). To date, only one group has reported STDP in ChIs. Fino and colleagues observed bidirectional plasticity in a majority of ChIs-Post-pre stimulation elicited an LTP in some cells and LTD in others, while pre-post stimulation results in only LTD. Using pharmacology, they found that both forms of plasticity depend upon mGluR activation (Fino et al., 2008). These findings contrast with the Suzuki study where HFS induced-LTP was insensitive to mGluR blockade (Suzuki et al., 2001b). Additionally, post-pre stimulation plasticity was inhibited by NMDA receptor blockade, suggesting that HFS induced-LTP occurs by another mechanism. Further exploration into LTP/LTD of the excitatory inputs to ChIs represents an exciting field of study, as changes in synaptic strength here may contribute to motor skill learning and habit formation.

\section{SUMMARY}

Even though ChIs only make up 1-2\% of all striatal cells, they send dense projections throughout the striatum. ACh can affect the output of the striatum directly or indirectly, and a wide variety of neurotransmitter systems can influence the activity of these cells. Given that ChIs are in a position to integrate synaptic inputs and modulate the output of the striatum, understanding the physiology of these cells will contribute to our knowledge of striatal function.

ChIs receive afferent inputs from a wide variety of sources which can arise either locally from within the striatum, or from brain regions as distant as the brainstem. Some of these neurotransmitter systems alter cellular excitability rapidly through their actions on ionotropic receptors, producing rapid electrical signals on a millisecond time scale. These changes in membrane properties affect the firing activity of the ChIs, and given the hundreds of thousands of synaptic contacts formed by each ChI, several other cell types are influenced by changes ACh release. The inherent membrane properties of ChIs allows them to be easily modified in either direction during neurotransmitter release: their depolarized resting membrane potential allows excitatory neurotransmitters to easily enhance action potential firing rate, and considering their tonic activity, inhibitory neurotransmitters will inhibit firing, reducing total cholinergic tone. Thus, because 
these cells are resting at some intermediate state of activity, they are sensitive to incoming afferents. In addition to the ionotropic receptors on these cells, ChIs express a wide variety of GPCRs. Activation of GPCRs can have a multitude of cellular effects, including the opening of ion channels, changes in plasticity or protein transcription (Altier, 2012; Rojas and Dingledine, 2013). The long time course of the signaling cascades downstream of GPCR activation could indicate that a temporary increase in neurotransmitter activity may lead to long-lasting modifications in ChI physiology that increases or decreases the cellular response to other incoming afferents. Given the sensitivity of these cells to various synaptic inputs, understanding $\mathrm{ChI}$ connectivity provides insight into the striatal network.

ACh has a wide variety of effects following release, either by directly activating receptors on postsynaptic cells or indirectly via the modulation of neurotransmitter release at terminals. Changes in striatal cholinergic tone will thus result in a complex series of downstream effects which ultimately may affect the striatal output neurons. Considering the multiple ACh-sensitive neurotransmitter systems that are involved in the striatal network, changes in receptor function or expression on any class of cells may result in a shift in the balance of these systems, potentially resulting in dysfunction. Understanding the nature of synaptic connectivity and the location of receptor expression therefor has a direct connection with human pathology. Using this knowledge in conjunction with an understanding of the changes that occur in disease, we can work toward the development of novel therapies that are aimed at counteracting neurotransmitter dysregulation.

Often times, we oversimplify the nature of the neurotransmitters released at a given terminal, neglecting the co-release of other neurotransmitters whose post-synaptic effects can differ from the primary neurotransmitter. Although there is evidence that co-release occurs, very few have looked in detail at the functional consequences of multiple transmitter release, or whether or not these neurotransmitters are released in sufficient amounts to contribute to cell physiology.

New genetic techniques can improve our understanding of striatal neurotransmission in both the normal and abnormal brain. Optogenetic manipulation of excitability in specific neuronal subtypes is providing important insights into connectivity throughout the nervous system. This robust technology has advantages over other methods of exogenous neural control and certainly provides a means to explore ChI efferent and afferent connections, as well as the nature of the neurotransmitter phenotypes that influence the excitability of these neurons. Extending these methods to in vivo analyses can help provide causal links between synaptic information and behavior.

CLARITY is a potentially groundbreaking new technique that allows high resolution visualization of subcellular structures such as individual synapses in the whole brain (Chung and Deisseroth, 2013). Because the preparation for CLARITY removes brain lipids, antibodies can easily permeate the entirety of the brain, permitting the resolution of the striatal connectome in total. This anatomical information will precisely elucidate the synaptic connectivity between striatal cell types.

Ultimately, ongoing efforts to improve our understanding of striatal ChIs will provide valuable insights into the physiology of this important brain area and help identify new pharmacotherapies for striatal disorders.

\section{ACKNOWLEDGMENTS}

The authors thank Lisa Won for helpful comments on the manuscript. Supported by Michael J. Fox Foundation for Parkinson Research and NS 064439 (UJK).

\section{REFERENCES}

Abercrombie, E. D., and DeBoer, P. (1997). Substantia nigra D1 receptors and stimulation of striatal cholinergic interneurons by dopamine: a proposed circuit mechanism. J. Neurosci. 17, 8498-8505.

Ahlskog, J. E., and Muenter, M. D. (2001). Frequency of levodopa-related dyskinesias and motor fluctuations as estimated from the cumulative literature. Mov. Disord. Off. J. Mov. Disord. Soc. 16, 448-458. doi: 10.1002/mds. 1090

Albin, R. L., Young, A. B., and Penney, J. B. (1989). The functional anatomy of basal ganglia disorders. Trends Neurosci. 12, 366-375. doi: 10.1016/01662236(89)90074-X

Alcantara, A. A., Mrzljak, L., Jakab, R. L., Levey, A. I., Hersch, S. M., and GoldmanRakic, P. S. (2001). Muscarinic $\mathrm{m} 1$ and $\mathrm{m} 2$ receptor proteins in local circuit and projection neurons of the primate striatum: anatomical evidence for cholinergic modulation of glutamatergic prefronto-striatal pathways. J. Comp. Neurol. 434, 445-460. doi: 10.1002/cne.1186

Allam, M. F., Campbell, M. J., Del Castillo, A. S., and Fernández-Crehuet Navajas, R. (2004). Parkinson's disease protects against smoking? Behav. Neurol. 15, 65-71. doi: 10.1155/2004/516302

Altier, C. (2012). GPCR and voltage-gated calcium channels (VGCC) signaling complexes. Subcell. Biochem. 63, 241-262. doi: 10.1007/978-94-007-4765-4_13

Ancín, I., Barabash, A., Vázquez-Álvarez, B., Santos, J. L., Sánchez-Morla, E., Martínez, J. L., et al. (2010). Evidence for association of the non-duplicated region of CHRNA7 gene with bipolar disorder but not with Schizophrenia. Psychiatr. Genet. 20, 289-297. doi: 10.1097/YPG.0b013e32833a9b7a

Aosaki, T., and Kawaguchi, Y. (1996). Actions of substance P on rat neostriatal neurons in vitro. J. Neurosci. 16, 5141-5153.

Aosaki, T., Kiuchi, K., and Kawaguchi, Y. (1998). Dopamine D1-like receptor activation excites rat striatal large aspiny neurons in vitro. J. Neurosci. 18, 5180-5190.

Aosaki, T., Tsubokawa, H., Ishida, A., Watanabe, K., Graybiel, A. M., and Kimura, M. (1994). Responses of tonically active neurons in the primate's striatum undergo systematic changes during behavioral sensorimotor conditioning. J. Neurosci. 14, 3969-3984.

Aouizerate, B., Guehl, D., Cuny, E., Rougier, A., Bioulac, B., Tignol, J., et al. (2004). Pathophysiology of obsessive-compulsive disorder: a necessary link between phenomenology, neuropsychology, imagery and physiology. Prog. Neurobiol. 72, 195-221. doi: 10.1016/j.pneurobio.2004.02.004

Apicella, P., Legallet, E., and Trouche, E. (1997). Responses of tonically discharging neurons in the monkey striatum to primary rewards delivered during different behavioral states. Exp. Brain Res. 116, 456-466. doi: 10.1007/PL00005773

Apicella, P., Ljungberg, T., Scarnati, E., and Schultz, W. (1991). Responses to reward in monkey dorsal and ventral striatum. Exp. Brain Res. 85, 491-500. doi: 10.1007/BF00231732

Arbuthnott, G. W., and Wickens, J. (2007). Space, time and dopamine. Trends Neurosci. 30, 62-69. doi: 10.1016/j.tins.2006.12.003

Arenas, E., Alberch, J., Perez-Navarro, E., Solsona, C., and Marsal, J. (1991). Neurokinin receptors differentially mediate endogenous acetylcholine release evoked by tachykinins in the neostriatum. J. Neurosci. 11, 2332-2338.

Arenas, E., Alberch, J., Sanchez Arroyos, R., and Marsal, J. (1990). Effect of opioids on acetylcholine release evoked by $\mathrm{K}+$ or glutamic acid from rat neostriatal slices. Brain Res. 523, 51-56. doi: 10.1016/0006-8993(90)91633-R

Aubert, I., Araujo, D. M., Cécyre, D., Robitaille, Y., Gauthier, S., and Quirion, R. (1992). Comparative alterations of nicotinic and muscarinic binding sites in Alzheimer's and Parkinson's diseases. J. Neurochem. 58, 529-541. doi: 10.1111/j.1471-4159.1992.tb09752.x

Azam, L., Winzer-Serhan, U., and Leslie, F. M. (2003). Co-expression of alpha7 and beta2 nicotinic acetylcholine receptor subunit mRNAs within rat brain cholinergic neurons. Neuroscience 119, 965-977. doi: 10.1016/S0306-4522(03)00220-3

Baba, Y., Higuchi, M.-A., Abe, H., Fukuyama, K., Onozawa, R., Uehara, Y., et al. (2012). Anti-cholinergics for axial symptoms in Parkinson's disease 
after subthalamic stimulation. Clin. Neurol. Neurosurg. 114, 1308-1311. doi: 10.1016/j.clineuro.2012.03.046

Bain, E. E., Robieson, W., Pritchett, Y., Garimella, T., Abi-Saab, W., Apostol, G., et al. (2013). A randomized, double-blind, placebo-controlled phase 2 study of $\alpha 4 \beta 2$ agonist ABT-894 in adults with ADHD. Neuropsychopharmacol. Off. Publ. Am. Coll. Neuropsychopharmacol. 38, 405-413. doi: 10.1038/npp.2012.194

Barroso-Chinea, P., and Bezard, E. (2010). Basal Ganglia circuits underlying the pathophysiology of levodopa-induced dyskinesia. Front. Neuroanat. 4:131. doi: 10.3389/fnana.2010.00131

Bar-Shira, A., Gana-Weisz, M., Gan-Or, Z., Giladi, E., Giladi, N., and Orr-Urtreger, A. (2014). CHRNB3 c.-57A $>$ G functional promoter change affects Parkinson's disease and smoking. Neurobiol. Aging 35, 2179.e1-2179.e6. doi: 10.1016/j. neurobiolaging.2014.03.014

Beaulieu, J.-M., and Gainetdinov, R. R. (2011). The physiology, signaling, and pharmacology of dopamine receptors. Pharmacol. Rev. 63, 182-217. doi: 10.1124/pr.110.002642

Beggiato, S., Antonelli, T., Tomasini, M. C., Tanganelli, S., Fuxe, K., Schwarcz, R., et al. (2013). Kynurenic acid, by targeting $\alpha 7$ nicotinic acetylcholine receptors, modulates extracellular GABA levels in the rat striatum in vivo. Eur. J. Neurosci. 37, 1470-1477. doi: 10.1111/ejn.12160

Bell, M. I., Richardson, P. J., and Lee, K. (2000). Histamine depolarizes cholinergic interneurones in the rat striatum via a $\mathrm{H}(1)$-receptor mediated action. Br. J. Pharmacol. 131, 1135-1142. doi: 10.1038/sj.bjp 0703692

Bell, M. I., Richardson, P. J., and Lee, K. (2002). Functional and molecular characterization of metabotropic glutamate receptors expressed in rat striatal cholinergic interneurones. J. Neurochem. 81, 142-149. doi: 10.1046/j.14714159.2002.00815.x

Berendse, H. W., and Groenewegen, H. J. (1990). Organization of the thalamostriatal projections in the rat, with special emphasis on the ventral striatum. J. Comp. Neurol. 299, 187-228. doi: 10.1002/cne.902990206

Berg, A. P., Sen, N., and Bayliss, D. A. (2007). TrpC3/C7 and Slo2.1 are molecular targets for metabotropic glutamate receptor signaling in rat striatal cholinergic interneurons. J. Neurosci. 27, 8845-8856. doi: 10.1523/JNEUROSCI.055107.2007

Bergson, C., Mrzljak, L., Smiley, J. F., Pappy, M., Levenson, R., and Goldman-Rakic, P. S. (1995). Regional, cellular, and subcellular variations in the distribution of D1 and D5 dopamine receptors in primate brain. J. Neurosci. 15, 7821-7836.

Bernard, V., Laribi, O., Levey, A. I., and Bloch, B. (1998). Subcellular redistribution of $\mathrm{m} 2$ muscarinic acetylcholine receptors in striatal interneurons in vivo after acute cholinergic stimulation. J. Neurosci. 18, 10207-10218.

Bernard, V., Normand, E., and Bloch, B. (1992). Phenotypical characterization of the rat striatal neurons expressing muscarinic receptor genes. J. Neurosci. 12, 3591-3600.

Bernard, V., Somogyi, P., and Bolam, J. P. (1997). Cellular, subcellular, and subsynaptic distribution of AMPA-type glutamate receptor subunits in the neostriatum of the rat. J. Neurosci. 17, 819-833.

Betarbet, R., Turner, R., Chockkan, V., DeLong, M. R., Allers, K. A., Walters, J., et al. (1997). Dopaminergic neurons intrinsic to the primate striatum. J. Neurosci. 17, 6761-6768.

Bettler, B., Kaupmann, K., Mosbacher, J., and Gassmann, M. (2004). Molecular structure and physiological functions of GABA(B) receptors. Physiol. Rev. 84, 835-867. doi: 10.1152/physrev.00036.2003

Bird, E. D., and Iversen, L. L. (1974). Huntington's chorea. Post-mortem measurement of glutamic acid decarboxylase, choline acetyltransferase and dopamine in basal ganglia. Brain J. Neurol. 97, 457-472. doi: 10.1093/brain/97.1.457

Bird, E. D., Spokes, E. G., Barnes, J., MacKay, A. V., Iversen, L. L., and Shepherd, M. (1977). Increased brain dopamine and reduced glutamic acid decarboxylase and choline acetyl transferase activity in schizophrenia and related psychoses. Lancet 2, 1157-1158. doi: 10.1016/S0140-6736(77)91542-2

Birket-Smith, E. (1974). Abnormal involuntary movements induced by anticholinergic therapy. Acta Neurol. Scand. 50, 801-811. doi: 10.1111/j.16000404.1974.tb02820.x

Blandina, P., Munari, L., Provensi, G., and Passani, M. B. (2012). Histamine neurons in the tuberomamillary nucleus: a whole center or distinct subpopulations? Front. Syst. Neurosci. 6:33. doi: 10.3389/fnsys.2012.00033

Blomeley, C., and Bracci, E. (2005). Excitatory effects of serotonin on rat striatal cholinergic interneurones. J. Physiol. 569, 715-721. doi: 10.1113/jphysiol.2005.098269
Bohr, I. J., Ray, M. A., McIntosh, J. M., Chalon, S., Guilloteau, D., McKeith, I. G., et al. (2005). Cholinergic nicotinic receptor involvement in movement disorders associated with Lewy body diseases. An autoradiography study using [(125)I] alpha-conotoxinMII in the striatum and thalamus. Exp. Neurol. 191, 292-300. doi: 10.1016/j.expneurol.2004.10.004

Bolam, J. P., Ingham, C. A., Izzo, P. N., Levey, A. I., Rye, D. B., Smith, A. D., et al. (1986). Substance P-containing terminals in synaptic contact with cholinergic neurons in the neostriatum and basal forebrain: a double immunocytochemical study in the rat. Brain Res. 397, 279-289. doi: 10.1016/0006-8993(86) 90629-3

Bolam, J. P., Wainer, B. H., and Smith, A. D. (1984). Characterization of cholinergic neurons in the rat neostriatum. A combination of choline acetyltransferase immunocytochemistry, Golgi-impregnation and electron microscopy. Neuroscience 12, 711-718. doi: 10.1016/0306-4522(84)90165-9

Bonsi, P., Cuomo, D., Ding, J., Sciamanna, G., Ulrich, S., Tscherter, A., et al. (2007). Endogenous serotonin excites striatal cholinergic interneurons via the activation of 5-HT 2C, 5-HT6, and 5-HT7 serotonin receptors: implications for extrapyramidal side effects of serotonin reuptake inhibitors. Neuropsychopharmacol. Off. Publ. Am. Coll. Neuropsychopharmacol. 32, 1840-1854. doi: 10.1038/sj.npp.1301294

Bonsi, P., De Persis, C., Calabresi, P., Bernardi, G., and Pisani, A. (2004). Coordinate high-frequency pattern of stimulation and calcium levels control the induction of LTP in striatal cholinergic interneurons. Learn. Mem. 11, 755-760. doi: $10.1101 / \mathrm{lm} .82104$

Bordia, T., Campos, C., McIntosh, J. M., and Quik, M. (2010). Nicotinic receptormediated reduction in L-DOPA-induced dyskinesias may occur via desensitization. J. Pharmacol. Exp. Ther. 333, 929-938. doi: 10.1124/jpet.109.162396

Britt, J. P., and McGehee, D. S. (2008). Presynaptic opioid and nicotinic receptor modulation of dopamine overflow in the nucleus accumbens. J. Neurosci. 28, 1672-1681. doi: 10.1523/JNEUROSCI.4275-07.2008

Brown, M. T. C., Tan, K. R., O’Connor, E. C., Nikonenko, I., Muller, D., and Lüscher, C. (2012). Ventral tegmental area GABA projections pause accumbal cholinergic interneurons to enhance associative learning. Nature 492, 452-456. doi: 10.1038 /nature11657

Brown, S. J., James, S., Reddington, M., and Richardson, P. J. (1990). Both A1 and A2a purine receptors regulate striatal acetylcholine release. J. Neurochem. 55, 31-38. doi: 10.1111/j.1471-4159.1990.tb08817.x

Cachope, R., Mateo, Y., Mathur, B. N., Irving, J., Wang, H.-L., Morales, M., et al. (2012). Selective activation of cholinergic interneurons enhances accumbal phasic dopamine release: setting the tone for reward processing. Cell Rep. 2, 33-41. doi: 10.1016/j.celrep.2012.05.011

Calabresi, P., Ascone, C. M., Centonze, D., Pisani, A., Sancesario, G., D’Angelo, V., et al. (1997). Opposite membrane potential changes induced by glucose deprivation in striatal spiny neurons and in large aspiny interneurons. J. Neurosci. 17, 1940-1949.

Calabresi, P., Centonze, D., Gubellini, P., Pisani, A., and Bernardi, G. (1998a). Blockade of M2-like muscarinic receptors enhances long-term potentiation at corticostriatal synapses. Eur. J. Neurosci. 10, 3020-3023. doi: 10.1111/j.14609568.1998.00348.x

Calabresi, P., Centonze, D., Pisani, A., and Bernardi, G. (1999). Metabotropic glutamate receptors and cell-type-specific vulnerability in the striatum: implication for ischemia and Huntington's disease. Exp. Neurol. 158, 97-108. doi: 10.1006/exnr.1999.7092

Calabresi, P., Centonze, D., Pisani, A., Sancesario, G., Gubellini, P., Marfia, G. A., et al. (1998b). Striatal spiny neurons and cholinergic interneurons express differential ionotropic glutamatergic responses and vulnerability: implications for ischemia and Huntington's disease. Ann. Neurol. 43, 586-597. doi: 10.1002/ana.410430506

Calabresi, P., Siniscalchi, A., Pisani, A., Stefani, A., Mercuri, N. B., and Bernardi, G. (1996). A field potential analysis on the effects of lamotrigine, GP 47779, and felbamate in neocortical slices. Neurology 47, 557-562. doi: 10.1212/WNL. 47.2.557

Campos, F., Alfonso, M., and Durán, R. (2010). In vivo modulation of alpha7 nicotinic receptors on striatal glutamate release induced by anatoxin-A. Neurochem. Int 56, 850-855. doi: 10.1016/j.neuint.2010.03.010

Cantello, R., Riccio, A., Gilli, M., Delsedime, M., Scarzella, L., Aguggia, M., et al. (1986). Bornaprine vs placebo in Parkinson disease: double-blind controlled cross-over trial in 30 patients. Ital. J. Neurol. Sci. 7, 139-143. doi: 10.1007/BF02230432 
Carpenedo, R., Pittaluga, A., Cozzi, A., Attucci, S., Galli, A., Raiteri, M., et al. (2001). Presynaptic kynurenate-sensitive receptors inhibit glutamate release. Eur. J. Neurosci. 13, 2141-2147. doi: 10.1046/j.0953-816x.2001.01592.x

Centonze, D., Grande, C., Usiello, A., Gubellini, P., Erbs, E., Martin, A. B., et al. (2003). Receptor subtypes involved in the presynaptic and postsynaptic actions of dopamine on striatal interneurons. J. Neurosci. 23, 6245-6254.

Centonze, D., Pisani, A., Bonsi, P., Giacomini, P., Bernardi, G., and Calabresi, P. (2001). Stimulation of nitric oxide-cGMP pathway excites striatal cholinergic interneurons via protein kinase G activation. J. Neurosci. 21, 1393-1400.

Cepeda, C., Itri, J. N., Flores-Hernández, J., Hurst, R. S., Calvert, C. R., and Levine, M. S. (2001). Differential sensitivity of medium- and large-sized striatal neurons to NMDA but not kainate receptor activation in the rat. Eur. J. Neurosci. 14, 1577-1589. doi: 10.1046/j.0953-816x.2001.01783.x

Cepeda, C., Wu, N., André, V. M., Cummings, D. M., and Levine, M. S. (2007). The corticostriatal pathway in Huntington's disease. Prog. Neurobiol. 81, 253-271. doi: 10.1016/j.pneurobio.2006.11.001

Chang, H. T. (1988). Dopamine-acetylcholine interaction in the rat striatum: a dual-labeling immunocytochemical study. Brain Res. Bull. 21, 295-304. doi: 10.1016/0361-9230(88)90244-4

Chang, H. T., and Kita, H. (1992). Interneurons in the rat striatum: relationships between parvalbumin neurons and cholinergic neurons. Brain Res. 574, 307-311. doi: 10.1016/0006-8993(92)90830-3

Chang, K. T., and Berg, D. K. (2001). Voltage-gated channels block nicotinic regulation of CREB phosphorylation and gene expression in neurons. Neuron 32, 855-865. doi: 10.1016/S0896-6273(01)00516-5

Chen, Q., Veenman, C. L., and Reiner, A. (1996). Cellular expression of ionotropic glutamate receptor subunits on specific striatal neuron types and its implication for striatal vulnerability in glutamate receptor-mediated excitotoxicity. Neuroscience 73, 715-731. doi: 10.1016/0306-4522(96)00011-5

Chudasama, Y., and Robbins, T. W. (2006). Functions of frontostriatal systems in cognition: comparative neuropsychopharmacological studies in rats, monkeys and humans. Biol. Psychol. 73, 19-38. doi: 10.1016/j.biopsycho.2006.01.005

Chuhma, N., Mingote, S., Moore, H., and Rayport, S. (2014). Dopamine neurons control striatal cholinergic neurons via regionally heterogeneous dopamine and glutamate signaling. Neuron 81, 901-912. doi: 10.1016/j.neuron.2013.12.027

Chuhma, N., Tanaka, K. F., Hen, R., and Rayport, S. (2011). Functional connectome of the striatal medium spiny neuron. J. Neurosci. 31, 1183-1192. doi: 10.1523/JNEUROSCI.3833-10.2011

Chung, K. A., Lobb, B. M., Nutt, J. G., and Horak, F. B. (2010). Effects of a central cholinesterase inhibitor on reducing falls in Parkinson disease. Neurology 75, 1263-1269. doi: 10.1212/WNL.0b013e3181f6128c

Chung, K., and Deisseroth, K. (2013). CLARITY for mapping the nervous system. Nat. Methods 10, 508-513. doi: 10.1038/nmeth.2481

Claye, L. H., Unterwald, E. M., Ho, A., and Kreek, M. J. (1996). Both dynorphin $\mathrm{A}(1-17)$ and [Des-Tyr1] dynorphin A(2-17) inhibit adenylyl cyclase activity in rat caudate putamen. J. Pharmacol. Exp. Ther. 277, 359-365.

Conn, P. J., Battaglia, G., Marino, M. J., and Nicoletti, F. (2005). Metabotropic glutamate receptors in the basal ganglia motor circuit. Nat. Rev. Neurosci. 6, 787-798. doi: 10.1038/nrn1763

Contant, C., Umbriaco, D., Garcia, S., Watkins, K. C., and Descarries, L. (1996). Ultrastructural characterization of the acetylcholine innervation in adult rat neostriatum. Neuroscience 71, 937-947. doi: 10.1016/0306-4522(95)00507-2

Cossette, M., Lecomte, F., and Parent, A. (2005). Morphology and distribution of dopaminergic neurons intrinsic to the human striatum. J. Chem. Neuroanat. 29, 1-11. doi: 10.1016/j.jchemneu.2004.08.007

Court, J. A., Piggott, M. A., Lloyd, S., Cookson, N., Ballard, C. G., McKeith, I. G., et al. (2000). Nicotine binding in human striatum: elevation in schizophrenia and reductions in dementia with Lewy bodies, Parkinson's disease and Alzheimer's disease and in relation to neuroleptic medication. Neuroscience 98 , 79-87. doi: 10.1016/S0306-4522(00)00071-3

Crain, S. M., and Shen, K. F. (1996). Modulatory effects of Gs-coupled excitatory opioid receptor functions on opioid analgesia, tolerance, and dependence. Neurochem. Res. 21, 1347-1351. doi: 10.1007/BF02 532375

Cubo, E., Fernández Jaén, A., Moreno, C., Anaya, B., González, M., and Kompoliti, K. (2008). Donepezil use in children and adolescents with tics and attention-deficit/hyperactivity disorder: an 18-week, single-center, dose-escalating, prospective, open-label study. Clin. Ther. 30, 182-189. doi: 10.1016/j.clinthera.2008.01.010
Da Cunha, C., Gomez, A.-A., and Blaha, C. D. (2012). The role of the basal ganglia in motivated behavior. Rev. Neurosci. 23, 747-767. doi: 10.1515/revneuro-20120063

Dalack, G. W., Healy, D. J., and Meador-Woodruff, J. H. (1998). Nicotine dependence in schizophrenia: clinical phenomena and laboratory findings. Am. J. Psychiatry 155, 1490-1501.

Dale, H. H., and Laidlaw, P. P. (1910). The physiological action of betaiminazolylethylamine. J. Physiol. 41, 318-344.

Dani, J. A. (2001). Overview of nicotinic receptors and their roles in the central nervous system. Biol. Psychiatry 49, 166-174. doi: 10.1016/S0006-3223(00)01011-8

Dautan, D., Huerta-Ocampo, I., Witten, I. B., Deisseroth, K., Bolam, J. P., Gerdjikov, T., et al. (2014). A major external source of cholinergic innervation of the striatum and nucleus accumbens originates in the brainstem. J. Neurosci. 34, 4509-4518. doi: 10.1523/JNEUROSCI.5071-13.2014

Dawson, V. L., Dawson, T. M., Filloux, F. M., and Wamsley, J. K. (1988). Evidence for dopamine D-2 receptors on cholinergic interneurons in the rat caudateputamen. Life Sci. 42, 1933-1939. doi: 10.1016/0024-3205(88)90492-4

Dawson, V. L., Dawson, T. M., and Wamsley, J. K. (1990). Muscarinic and dopaminergic receptor subtypes on striatal cholinergic interneurons. Brain Res. Bull. 25, 903-912. doi: 10.1016/0361-9230(90)90186-4

Dean, B., Crook, J. M., Opeskin, K., Hill, C., Keks, N., and Copolov, D. L. (1996). The density of muscarinic M1 receptors is decreased in the caudate-putamen of subjects with schizophrenia. Mol. Psychiatry 1, 54-58.

DeBoer, P., Abercrombie, E. D., Heeringa, M., and Westerink, B. H. (1993). Differential effect of systemic administration of bromocriptine and L-dopa on the release of acetylcholine from striatum of intact and 6-OHDA-treated rats. Brain Res. 608, 198-203. doi: 10.1016/0006-8993(93)91459-6

DeBoer, P., and Westerink, B. H. (1994). GABAergic modulation of striatal cholinergic interneurons: an in vivo microdialysis study. J. Neurochem. 62, 70-75. doi: 10.1046/j.1471-4159.1994.62010070.x

Del Barrio, L., Egea, J., León, R., Romero, A., Ruiz, A., Montero, M., et al. (2011). Calcium signalling mediated through $\alpha 7$ and non- $\alpha 7 \mathrm{nAChR}$ stimulation is differentially regulated in bovine chromaffin cells to induce catecholamine release. Br. J. Pharmacol. 162, 94-110. doi: 10.1111/j.1476-5381.2010.01034.x

DeLong, M. R. (1990). Primate models of movement disorders of basal ganglia origin. Trends Neurosci. 13, 281-285. doi: 10.1016/0166-2236(90)90110-V

Deng, P., Zhang, Y., and Xu, Z. C. (2007a). Involvement of I(h) in dopamine modulation of tonic firing in striatal cholinergic interneurons. J. Neurosci. 27, 3148-3156. doi: 10.1523/JNEUROSCI.5535-06.2007

Deng, Y. P., Xie, J. P., Wang, H. B., Lei, W. L., Chen, Q., and Reiner, A. (2007b). Differential localization of the GluR1 and GluR2 subunits of the AMPA-type glutamate receptor among striatal neuron types in rats. J. Chem. Neuroanat. 33, 167-192. doi: 10.1016/j.jchemneu.2007.02.008

De Rover, M., Lodder, J. C., Kits, K. S., Schoffelmeer, A. N. M., and Brussaard, A. B. (2002). Cholinergic modulation of nucleus accumbens medium spiny neurons. Eur. J. Neurosci. 16, 2279-2290. doi: 10.1046/j.1460-9568.2002.02289.x

Devan, B. D., Hong, N. S., and McDonald, R. J. (2011). Parallel associative processing in the dorsal striatum: segregation of stimulus-response and cognitive control subregions. Neurobiol. Learn. Mem. 96, 95-120. doi: 10.1016/j.nlm.2011.06.002

Dimova, R., Vuillet, J., Nieoullon, A., and Kerkerian-Le Goff, L. (1993). Ultrastructural features of the choline acetyltransferase-containing neurons and relationships with nigral dopaminergic and cortical afferent pathways in the rat striatum. Neuroscience 53, 1059-1071. doi: 10.1016/0306-4522(93)90489-3

Ding, J. B., Guzman, J. N., Peterson, J. D., Goldberg, J. A., and Surmeier, D. J. (2010). Thalamic gating of corticostriatal signaling by cholinergic interneurons. Neuron 67, 294-307. doi: 10.1016/j.neuron.2010.06.017

Ding, J., Guzman, J. N., Tkatch, T., Chen, S., Goldberg, J. A., Ebert, P. J., et al. (2006). RGS4-dependent attenuation of M4 autoreceptor function in striatal cholinergic interneurons following dopamine depletion. Nat. Neurosci. 9, 832-842. doi: 10.1038/nn1700

Ding, S., Wei, W., and Zhou, F.-M. (2011a). Molecular and functional differences in voltage-activated sodium currents between GABA projection neurons and dopamine neurons in the substantia nigra. J. Neurophysiol. 106, 3019-3034. doi: 10.1152/jn.00305.2011

Ding, Y., Won, L., Britt, J. P., Lim, S. A. O., McGehee, D. S., and Kang, U. J. (2011b). Enhanced striatal cholinergic neuronal activity mediates L-DOPAinduced dyskinesia in parkinsonian mice. Proc. Natl. Acad. Sci. U.S.A. 108, 840-845. doi: 10.1073/pnas.1006511108 
Diraddo, J. O., Miller, E. J., Hathaway, H. A., Grajkowska, E., Wroblewska, B., Wolfe, B. B., et al. (2014). A real-time method for measuring cAMP production modulated by Gai/o-coupled metabotropic glutamate receptors. J. Pharmacol. Exp. Ther. 349, 373-382. doi: 10.1124/jpet.113.211532

Dodt, H. U., and Misgeld, U. (1986). Muscarinic slow excitation and muscarinic inhibition of synaptic transmission in the rat neostriatum. J. Physiol. 380, 593-608.

Dubach, M., Schmidt, R., Kunkel, D., Bowden, D. M., Martin, R., and German, D. C. (1987). Primate neostriatal neurons containing tyrosine hydroxylase: immunohistochemical evidence. Neurosci. Lett. 75, 205-210. doi: 10.1016/03043940(87)90298-9

Durany, N., Zöchling, R., Boissl, K. W., Paulus, W., Ransmayr, G., Tatschner, T., et al. (2000). Human post-mortem striatal alpha4beta2 nicotinic acetylcholine receptor density in schizophrenia and Parkinson's syndrome. Neurosci. Lett. 287, 109-112. doi: 10.1016/S0304-3940(00)01144-7

Ellens, D. J., and Leventhal, D. K. (2013). Review: electrophysiology of basal ganglia and cortex in models of Parkinson disease. J. Park. Dis. 3, 241-254. doi: 10.3233/JPD-130204

English, B. A., Hahn, M. K., Gizer, I. R., Mazei-Robison, M., Steele, A., Kurnik, D. M., et al. (2009). Choline transporter gene variation is associated with attention-deficit hyperactivity disorder. J. Neurodev. Disord. 1, 252-263. doi: 10.1007/s11689-009-9033-8

English, D. F., Ibanez-Sandoval, O., Stark, E., Tecuapetla, F., Buzsaki, G., Deisseroth, K., et al. (2011). Novel GABAergic circuits mediate the reinforcement-related signals of striatal cholinergic interneurons. Nat. Neurosci. 15, 123-130. doi: 10.1038/nn.2984

Enna, S. J., Bennett, J. P. Jr., Bylund, D. B., Snyder, S. H., Bird, E. D., and Iversen, L. L. (1976a). Alterations of brain neurotransmitter receptor binding in Huntington's chorea. Brain Res. 116, 531-537. doi: 10.1016/00068993(76) $90502-3$

Enna, S. J., Bird, E. D., Bennett, J. P. Jr., Bylund, D. B., Yamamura, H. I., Iversen, L. L., et al. (1976b). Huntington's chorea. Changes in neurotransmitter receptors in the brain. N. Engl. J. Med. 294, 1305-1309. doi: 10.1056/NEJM197606102942402

Exley, R., Clements, M. A., Hartung, H., McIntosh, J. M., Franklin, M., Bermudez, I., et al. (2013). Striatal dopamine transmission is reduced after chronic nicotine with a decrease in a6-nicotinic receptor control in nucleus accumbens. Eur. J. Neurosci. 22, 1379-1389. doi: 10.1111/ejn.12298

Fabbrini, G., Brotchie, J. M., Grandas, F., Nomoto, M., and Goetz, C. G. (2007). Levodopa-induced dyskinesias. Mov. Disord. Off. J. Mov. Disord. Soc. 22, 1379-1389. doi: 10.1002/mds.21475

Fallon, J. H., and Leslie, F. M. (1986). Distribution of dynorphin and enkephalin peptides in the rat brain. J. Comp. Neurol. 249, 293-336. doi: $10.1002 /$ cne. 902490302

Feng, Z.-J., Zhang, X., and Chergui, K. (2014). Allosteric modulation of NMDA receptors alters neurotransmission in the striatum of a mouse model of Parkinson's disease. Exp. Neurol. 255, 154-160. doi: 10.1016/j.expneurol.2014.03.001

Fenster, C. P., Rains, M. F., Noerager, B., Quick, M. W., and Lester, R. A. (1997). Influence of subunit composition on desensitization of neuronal acetylcholine receptors at low concentrations of nicotine. J. Neurosci. 17, 5747-5759.

Fernandez, H. H. (2012). Updates in the medical management of Parkinson disease. Cleve. Clin. J. Med. 79, 28-35. doi: 10.3949/ccjm.78gr.11005

Fino, E., Deniau, J.-M., and Venance, L. (2008). Cell-specific spike-timingdependent plasticity in GABAergic and cholinergic interneurons in corticostriatal rat brain slices. J. Physiol. 586, 265-282. doi: 10.1113/jphysiol.2007. 144501

Fisher, J. L., and Dani, J. A. (2000). Nicotinic receptors on hippocampal cultures can increase synaptic glutamate currents while decreasing the NMDAreceptor component. Neuropharmacology 39, 2756-2769. doi: 10.1016/S00283908(00)00102-7

Fox, S. H., Katzenschlager, R., Lim, S.-Y., Ravina, B., Seppi, K., Coelho, M., et al. (2011). The movement disorder society evidence-based medicine review update: treatments for the motor symptoms of Parkinson's disease. Mov. Disord. Off. J. Mov. Disord. Soc. 26(Suppl. 3), S2-S41. doi: 10.1002/mds.23829

Galarraga, E., Hernández-López, S., Reyes, A., Miranda, I., Bermudez-Rattoni, F., Vilchis, C., et al. (1999). Cholinergic modulation of neostriatal output: a functional antagonism between different types of muscarinic receptors. J. Neurosci. $19,3629-3638$.
Garcia-Munoz, M., Patino, P., Young, S. J., and Groves, P. M. (1996). Effects of nicotine on dopaminergic nigrostriatal axons requires stimulation of presynaptic glutamatergic receptors. J. Pharmacol. Exp. Ther. 277, 1685-1693.

Gasser, T. (2009). Molecular pathogenesis of Parkinson disease: insights from genetic studies. Expert Rev. Mol. Med. 11, e22. doi: 10.1017/S1462399409001148

Gerfen, C. R., Herkenham, M., and Thibault, J. (1987). The neostriatal mosaic: II. Patch- and matrix-directed mesostriatal dopaminergic and non-dopaminergic systems. J. Neurosci. 7, 3915-3934.

Gilman, S., Koeppe, R. A., Nan, B., Wang, C.-N., Wang, X., Junck, L., et al. (2010). Cerebral cortical and subcortical cholinergic deficits in parkinsonian syndromes. Neurology 74, 1416-1423. doi: 10.1212/WNL.0b013e3181 dcla55

Girod, R., Barazangi, N., McGehee, D., and Role, L. W. (2000). Facilitation of glutamatergic neurotransmission by presynaptic nicotinic acetylcholine receptors. Neuropharmacology 39, 2715-2725. doi: 10.1016/S0028-3908(00)00145-3

Goetz, C. G. (2011). The history of Parkinson's disease: early clinical descriptions and neurological therapies. Cold Spring Harb. Perspect. Med. 1:a008862. doi: $10.1101 /$ cshperspect.a008862

Gomez-Mancilla, B., and Bédard, P. J. (1993). Effect of nondopaminergic drugs on L-dopa-induced dyskinesias in MPTP-treated monkeys. Clin. Neuropharmacol. 16, 418-427. doi: 10.1097/00002826-199310000-00004

Gonzales, K. K., Pare, J.-F., Wichmann, T., and Smith, Y. (2013). GABAergic inputs from direct and indirect striatal projection neurons onto cholinergic interneurons in the primate putamen. J. Comp. Neurol. 521, 2502-2522. doi: $10.1002 /$ cne. 23295

Gotti, C., Moretti, M., Bohr, I., Ziabreva, I., Vailati, S., Longhi, R., et al. (2006a). Selective nicotinic acetylcholine receptor subunit deficits identified in Alzheimer's disease, Parkinson's disease and dementia with Lewy bodies by immunoprecipitation. Neurobiol. Dis. 23, 481-489. doi: 10.1016/j.nbd.2006.04.005

Gotti, C., Zoli, M., and Clementi, F. (2006b). Brain nicotinic acetylcholine receptors: native subtypes and their relevance. Trends Pharmacol. Sci. 27, 482-491. doi: 10.1016/j.tips.2006.07.004

Götz, T., Kraushaar, U., Geiger, J., Lübke, J., Berger, T., and Jonas, P. (1997). Functional properties of AMPA and NMDA receptors expressed in identified types of basal ganglia neurons. J. Neurosci. 17, 204-215.

Grace, A. A., and Bunney, B. S. (1984). The control of firing pattern in nigral dopamine neurons: single spike firing. J. Neurosci. 4, 2866-2876.

Grady, S. R., Salminen, O., Laverty, D. C., Whiteaker, P., McIntosh, J. M., Collins, A. C., et al. (2007). The subtypes of nicotinic acetylcholine receptors on dopaminergic terminals of mouse striatum. Biochem. Pharmacol. 74, 1235-1246. doi: 10.1016/j.bcp.2007.07.032

Gras, C., Amilhon, B., Lepicard, E. M., Poirel, O., Vinatier, J., Herbin, M., et al. (2008). The vesicular glutamate transporter VGLUT3 synergizes striatal acetylcholine tone. Nat. Neurosci. 11, 292-300. doi: 10.1038/nn2052

Gray, R., Rajan, A. S., Radcliffe, K. A., Yakehiro, M., and Dani, J. A. (1996). Hippocampal synaptic transmission enhanced by low concentrations of nicotine. Nature 383, 713-716. doi: 10.1038/383713a0

Gross, R. A., Moises, H. C., Uhler, M. D., and Macdonald, R. L. (1990). Dynorphin A and cAMP-dependent protein kinase independently regulate neuronal calcium currents. Proc. Natl. Acad. Sci. U.S.A. 87, 7025-7029. doi: 10.1073/pnas.87.18.7025

Guan, L., Wang, B., Chen, Y., Yang, L., Li, J., Qian, Q., et al. (2009). A high-density single-nucleotide polymorphism screen of 23 candidate genes in attention deficit hyperactivity disorder: suggesting multiple susceptibility genes among Chinese Han population. Mol. Psychiatry 14, 546-554. doi: 10.1038/sj.mp. 4002139

Guatteo, E., Yee, A., McKearney, J., Cucchiaroni, M. L., Armogida, M., Berretta, N., et al. (2013). Dual effects of L-DOPA on nigral dopaminergic neurons. Exp. Neurol. 247, 582-594. doi: 10.1016/j.expneurol.2013.02.009

Haas, H. L., Sergeeva, O. A., and Selbach, O. (2008). Histamine in the nervous system. Physiol. Rev. 88, 1183-1241. doi: 10.1152/physrev.00043.2007

Haber, S. N., Fudge, J. L., and McFarland, N. R. (2000). Striatonigrostriatal pathways in primates form an ascending spiral from the shell to the dorsolateral striatum. J. Neurosci. 20, 2369-2382. doi: 10.0270-6474/00/202369-14

Haj-Dahmane, S., Hamon, M., and Lanfumey, L. (1991). K+ channel and 5-hydroxytryptamine1A autoreceptor interactions in the rat dorsal raphe nucleus: an in vitro electrophysiological study. Neuroscience 41, 495-505. doi: $10.1016 / 0306-4522(91) 90344-\mathrm{N}$ 
Hammond, P., and Brimijoin, S. (1988). Acetylcholinesterase in Huntington's and Alzheimer's diseases: simultaneous enzyme assay and immunoassay of multiple brain regions. J. Neurochem. 50, 1111-1116. doi: 10.1111/j.14714159.1988.tb10580.x

Hannestad, J. O., Cosgrove, K. P., DellaGioia, N. F., Perkins, E., Bois, F., Bhagwagar, Z., et al. (2013). Changes in the cholinergic system between bipolar depression and euthymia as measured with [123I]5IA single photon emission computed tomography. Biol. Psychiatry 74, 768-776. doi: 10.1016/j.biopsych.2013. 04.004

Hattori, T., Singh, V. K., McGeer, E. G., and McGeer, P. L. (1976). Immunohistochemical localization of choline acetyltransferase containing neostriatal neurons and their relationship with dopaminergic synapses. Brain Res. 102, 164-173. doi: 10.1016/0006-8993(76)90583-7

Hattori, T., Takada, M., Moriizumi, T., and Van der Kooy, D. (1991). Single dopaminergic nigrostriatal neurons form two chemically distinct synaptic types: possible transmitter segregation within neurons. J. Comp. Neurol. 309, 391-401. doi: $10.1002 /$ cne. 903090308

Hauber, W., and Schmidt, W. J. (1994). Differential effects of lesions of the dorsomedial and dorsolateral caudate-putamen on reaction time performance in rats. Behav. Brain Res. 60, 211-215. doi: 10.1016/0166-4328(94)90149-X

Hauser, R. A., and Olanow, C. W. (1993). Orobuccal dyskinesia associated with trihexyphenidyl therapy in a patient with Parkinson's disease. Mov. Disord. Off. J. Mov. Disord. Soc. 8, 512-514. doi: 10.1002/mds.870080417

Haydar, S. N., and Dunlop, J. (2010). Neuronal nicotinic acetylcholine receptors targets for the development of drugs to treat cognitive impairment associated with schizophrenia and Alzheimer's disease. Curr. Top. Med. Chem. 10, 144-152. doi: 10.2174/156802610790410983

Hayslett, R. L., and Tizabi, Y. (2003). Effects of donepezil on DOI-induced head twitch response in mice: implications for Tourette syndrome. Pharmacol. Biochem. Behav. 76, 409-415. doi: 10.1016/j.pbb.2003.08.015

Hebb, C. O., and Silver, A. (1961). Gradient of choline acetylase activity. Nature 189, 123-125. doi: 10.1038/189123a0

Hellström-Lindahl, E., and Court, J. A. (2000). Nicotinic acetylcholine receptors during prenatal development and brain pathology in human aging. Behav. Brain Res. 113, 159-168. doi: 10.1016/S0166-4328(00)00210-2

Henny, P., Brown, M. T. C., Northrop, A., Faunes, M., Ungless, M. A., Magill, P. J., et al. (2012). Structural correlates of heterogeneous in vivo activity of midbrain dopaminergic neurons. Nat. Neurosci. 15, 613-619. doi: 10.1038/ nn.3048

Hernández-Echeagaray, E., Galarraga, E., and Bargas, J. (1998). 3-Alpha-chloroimperialine, a potent blocker of cholinergic presynaptic modulation of glutamatergic afferents in the rat neostriatum. Neuropharmacology 37, 1493-1502. doi: 10.1016/S0028-3908(98)00131-2

Hersch, S. M., Gutekunst, C. A., Rees, H. D., Heilman, C. J., and Levey, A. I. (1994). Distribution of m1-m4 muscarinic receptor proteins in the rat striatum: light and electron microscopic immunocytochemistry using subtype-specific antibodies. J. Neurosci. 14, 3351-3363.

Higashi, S., Biskup, S., West, A. B., Trinkaus, D., Dawson, V. L., Faull, R. L. M., et al. (2007). Localization of Parkinson's disease-associated LRRK2 in normal and pathological human brain. Brain Res. 1155, 208-219. doi: 10.1016/j.brainres.2007.04.034

Higley, M. J., Gittis, A. H., Oldenburg, I. A., Balthasar, N., Seal, R. P., Edwards, R. H., et al. (2011). Cholinergic interneurons mediate fast VGluT3-dependent glutamatergic transmission in the striatum. PLoS ONE 6:e19155. doi: 10.1371/journal.pone.0019155

Hiley, C. R., and Bird, E. D. (1974). Decreased muscarinic receptor concentration in post-mortem brain in Huntington's chorea. Brain Res. 80, 355-358. doi: 10.1016/0006-8993(74)90700-8

Holt, D. J., Herman, M. M., Hyde, T. M., Kleinman, J. E., Sinton, C. M., German, D. C., et al. (1999). Evidence for a deficit in cholinergic interneurons in the striatum in schizophrenia. Neuroscience 94, 21-31. doi: 10.1016/S03064522(99)00279-1

Hong, C.-J., Lai, I.-C., Liou, L.-L., and Tsai, S.-J. (2004). Association study of the human partially duplicated alpha7 nicotinic acetylcholine receptor genetic variant with bipolar disorder. Neurosci. Lett. 355, 69-72. doi: 10.1016/j.neulet.2003.10.043

Howe, A. R., and Surmeier, D. J. (1995). Muscarinic receptors modulate N-, P-, and L-type $\mathrm{Ca} 2+$ currents in rat striatal neurons through parallel pathways. J. Neurosci. 15, 458-469.
Hristova, A. H., and Koller, W. C. (2000). Early Parkinson's disease: what is the best approach to treatment. Drugs Aging 17, 165-181. doi: 10.2165/00002512200017030-00002

Hsu, K. S., Yang, C. H., Huang, C. C., and Gean, P. W. (1996). Carbachol induces inward current in neostriatal neurons through M1-like muscarinic receptors. Neuroscience 73, 751-760. doi: 10.1016/0306-4522(96)00066-8

Hu, M., Liu, Q., Chang, K. T., and Berg, D. K. (2002). Nicotinic regulation of CREB activation in hippocampal neurons by glutamatergic and nonglutamatergic pathways. Mol. Cell. Neurosci. 21, 616-625. doi: 10.1006/mcne.2002.1202

Huot, P., Lévesque, M., and Parent, A. (2007). The fate of striatal dopaminergic neurons in Parkinson's disease and Huntington's chorea. Brain J. Neurol. 130, 222-232. doi: 10.1093/brain/awl332

Hyland, B. I., Reynolds, J. N. J., Hay, J., Perk, C. G., and Miller, R. (2002). Firing modes of midbrain dopamine cells in the freely moving rat. Neuroscience 114 , 475-492. doi: 10.1016/S0306-4522(02)00267-1

Ibáñez-Sandoval, O., Tecuapetla, F., Unal, B., Shah, F., Koós, T., and Tepper, J. M. (2010). Electrophysiological and morphological characteristics and synaptic connectivity of tyrosine hydroxylase-expressing neurons in adult mouse striatum. J. Neurosci. 30, 6999-7016. doi: 10.1523/JNEUROSCI.5996-09.2010

Innis, R. B., and Aghajanian, G. K. (1987). Pertussis toxin blocks 5-HT1A and $\mathrm{GABAB}$ receptor-mediated inhibition of serotonergic neurons. Eur. J. Pharmacol. 143, 195-204. doi: 10.1016/0014-2999(87)90533-4

Inokawa, H., Yamada, H., Matsumoto, N., Muranishi, M., and Kimura, M. (2010). Juxtacellular labeling of tonically active neurons and phasically active neurons in the rat striatum. Neuroscience 168, 395-404. doi: 10.1016/j.neuroscience.2010.03.062

Jabourian, M., Venance, L., Bourgoin, S., Ozon, S., Pérez, S., Godeheu, G., et al. (2005). Functional mu opioid receptors are expressed in cholinergic interneurons of the rat dorsal striatum: territorial specificity and diurnal variation. Eur. J. Neurosci. 21, 3301-3309. doi: 10.1111/j.1460-9568.2005.04154.x

Jackisch, R., Hotz, H., and Hertting, G. (1993). No evidence for presynaptic opioid receptors on cholinergic, but presence of kappa-receptors on dopaminergic neurons in the rabbit caudate nucleus: involvement of endogenous opioids. Naunyn. Schmiedebergs Arch. Pharmacol. 348, 234-241. doi: 10.1007/BF00169150

Jin, S., and Fredholm, B. B. (1997). Adenosine A2A receptor stimulation increases release of acetylcholine from rat hippocampus but not striatum, and does not affect catecholamine release. Naunyn. Schmiedebergs Arch. Pharmacol. 355, 48-56. doi: 10.1007/PL00004917

Johnson, M. D., and Yee, A. G. (1995). Ultrastructure of electrophysiologicallycharacterized synapses formed by serotonergic raphe neurons in culture. Neuroscience 67, 609-623. doi: 10.1016/0306-4522(95)00010-G

Jollivet, C., Montero-Menei, C. N., Venier-Julienne, M.-C., Sapin, A., Benoit, J.-P., and Menei, P. (2004). Striatal tyrosine hydroxylase immunoreactive neurons are induced by L-dihydroxyphenylalanine and nerve growth factor treatment in 6-hydroxydopamine lesioned rats. Neurosci. Lett. 362, 79-82. doi: 10.1016/j.neulet.2004.02.068

Jones, I. W., Bolam, J. P., and Wonnacott, S. (2001). Presynaptic localisation of the nicotinic acetylcholine receptor beta2 subunit immunoreactivity in rat nigrostriatal dopaminergic neurones. J. Comp. Neurol. 439, 235-247. doi: 10.1002/cne. 1345

Jucaite, A., Öhd, J., Potter, A. S., Jaeger, J., Karlsson, P., Hannesdottir, K., et al. (2014). A randomized, double-blind, placebo-controlled crossover study of $\alpha 4 \beta 2^{*}$ nicotinic acetylcholine receptor agonist AZD1446 (TC-6683) in adults with attention-deficit/hyperactivity disorder. Psychopharmacology (Berl.) 231, 1251-1265. doi: 10.1007/s00213-013-3116-7

Kaiser, S., and Wonnacott, S. (2000). Alpha-bungarotoxin-sensitive nicotinic receptors indirectly modulate $[(3) \mathrm{H}]$ dopamine release in rat striatal slices via glutamate release. Mol. Pharmacol. 58, 312-318. doi: 10.1124/mol.58.2.312

Kataoka, Y., Kalanithi, P. S. A., Grantz, H., Schwartz, M. L., Saper, C., Leckman, J. F., et al. (2010). Decreased number of parvalbumin and cholinergic interneurons in the striatum of individuals with Tourette syndrome. J. Comp. Neurol. 518, 277-291. doi: 10.1002/cne.22206

Katzenschlager, R., Sampaio, C., Costa, J., and Lees, A. (2003). Anticholinergics for symptomatic management of Parkinson's disease. Cochrane Database Syst. Rev. CD003735. doi: 10.1002/14651858.CD003735

Kawaguchi, Y. (1993). Physiological, morphological, and histochemical characterization of three classes of interneurons in rat neostriatum. J. Neurosci. 13, 4908-4923. 
Keath, J. R., Iacoviello, M. P., Barrett, L. E., Mansvelder, H. D., and McGehee, D. S. (2007). Differential modulation by nicotine of substantia nigra versus ventral tegmental area dopamine neurons. J. Neurophysiol. 98, 3388-3396. doi: 10.1152/jn.00760.2007

Kelley, A. E. (2004). Ventral striatal control of appetitive motivation: role in ingestive behavior and reward-related learning. Neurosci. Biobehav. Rev. 27, 765-776. doi: 10.1016/j.neubiorev.2003.11.015

Kimura, M., Rajkowski, J., and Evarts, E. (1984). Tonically discharging putamen neurons exhibit set-dependent responses. Proc. Natl. Acad. Sci. U.S.A. 81, 4998-5001. doi: 10.1073/pnas.81.15.4998

Klink, R., de Kerchove d'Exaerde, A., Zoli, M., and Changeux, J. P. (2001). Molecular and physiological diversity of nicotinic acetylcholine receptors in the midbrain dopaminergic nuclei. J. Neurosci. 21, 1452-1463.

Koob, G. F. (1992). Neural mechanisms of drug reinforcement. Ann. N.Y. Acad. Sci. 654, 171-191. doi: 10.1111/j.1749-6632.1992.tb25966.x

Koranda, J. L., Cone, J. J., McGehee, D. S., Roitman, M. F., Beeler, J. A., and Zhuang, X. (2014). Nicotinic receptors regulate the dynamic range of dopamine release in vivo. J. Neurophysiol. 111, 103-111. doi: 10.1152/jn.00269.2013

Kostic, V., Przedborski, S., Flaster, E., and Sternic, N. (1991). Early development of levodopa-induced dyskinesias and response fluctuations in young-onset Parkinson's disease. Neurology 41, 202-205. doi: 10.1212/WNL.41.2_Part_1.202

Kravitz, A. V., Freeze, B. S., Parker, P. R. L., Kay, K., Thwin, M. T., Deisseroth, K., et al. (2010). Regulation of parkinsonian motor behaviours by optogenetic control of basal ganglia circuitry. Nature 466, 622-626. doi: 10.1038/nature09159

Kubota, Y., Inagaki, S., Shimada, S., Kito, S., Eckenstein, F., and Tohyama, M. (1987). Neostriatal cholinergic neurons receive direct synaptic inputs from dopaminergic axons. Brain Res. 413, 179-184. doi: 10.1016/00068993(87)90167-3

Kulak, J. M., Musachio, J. L., McIntosh, J. M., and Quik, M. (2002). Declines in different beta $2^{*}$ nicotinic receptor populations in monkey striatum after nigrostriatal damage. J. Pharmacol. Exp. Ther. 303, 633-639. doi: 10.1124/jpet.102.039347

Kumar, N., Van Gerpen, J. A., Bower, J. H., and Ahlskog, J. E. (2005). Levodopadyskinesia incidence by age of Parkinson's disease onset. Mov. Disord. Off. J. Mov. Disord. Soc. 20, 342-344. doi: 10.1002/mds.20360

Kumar, P., and Kumar, A. (2009). Protective effect of rivastigmine against 3nitropropionic acid-induced Huntington's disease like symptoms: possible behavioural, biochemical and cellular alterations. Eur. J. Pharmacol. 615, 91-101. doi: 10.1016/j.ejphar.2009.04.058

Künzle, H. (1975). Bilateral projections from precentral motor cortex to the putamen and other parts of the basal ganglia. An autoradiographic study in Macaca fascicularis. Brain Res. 88, 195-209. doi: 10.1016/0006-8993(75)90384-4

Kurokawa, M., Kirk, I. P., Kirkpatrick, K. A., Kase, H., and Richardson, P. J. (1994). Inhibition by KF17837 of adenosine A2A receptor-mediated modulation of striatal GABA and ACh release. Br. J. Pharmacol. 113, 43-48. doi: 10.1111/j.1476-5381.1994.tb16171.x

Landwehrmeyer, G. B., Standaert, D. G., Testa, C. M., Penney, J. B. Jr., and Young, A. B. (1995). NMDA receptor subunit mRNA expression by projection neurons and interneurons in rat striatum. J. Neurosci. 15, 5297-5307.

Lange, K. W., Wells, F. R., Jenner, P., and Marsden, C. D. (1993). Altered muscarinic and nicotinic receptor densities in cortical and subcortical brain regions in Parkinson's disease. J. Neurochem. 60, 197-203. doi: 10.1111/j.14714159.1993.tb05838.x

Lanska, D. J. (2010). Chapter 33: the history of movement disorders. Handb. Clin. Neurol. 95, 501-546. doi: 10.1016/S0072-9752(08)02133-7

Lapper, S. R., and Bolam, J. P. (1992). Input from the frontal cortex and the parafascicular nucleus to cholinergic interneurons in the dorsal striatum of the rat. Neuroscience 51, 533-545. doi: 10.1016/0306-4522(92)90293-B

Lee, J., Laurin, N., Crosbie, J., Ickowicz, A., Pathare, T., Malone, M., et al. (2008). Association study of the nicotinic acetylcholine receptor alpha4 subunit gene, CHRNA4, in attention-deficit hyperactivity disorder. Genes Brain Behav. 7, 53-60. doi: 10.1111/j.1601-183X.2007.00325.x

Lee, K., Dixon, A. K., Freeman, T. C., and Richardson, P. J. (1998). Identification of an ATP-sensitive potassium channel current in rat striatal cholinergic interneurones. J. Physiol. 510(Pt 2), 441-453. doi: 10.1111/j.1469-7793.1998.441bk.x

Lehmann, J., and Langer, S. Z. (1982). Muscarinic receptors on dopamine terminals in the cat caudate nucleus: neuromodulation of $[3 \mathrm{H}]$ dopamine release in vitro by endogenous acetylcholine. Brain Res. 248, 61-69. doi: 10.1016/00068993(82)91147-7
Lehmann, J., and Langer, S. Z. (1983). The striatal cholinergic interneuron: synaptic target of dopaminergic terminals? Neuroscience 10, 1105-1120. doi: 10.1016/0306-4522(83)90102-1

Le Moine, C., Kieffer, B., Gaveriaux-Ruff, C., Befort, K., and Bloch, B. (1994). Deltaopioid receptor gene expression in the mouse forebrain: localization in cholinergic neurons of the striatum. Neuroscience 62, 635-640. doi: 10.1016/03064522(94)90464-2

Le Novère, N., Zoli, M., and Changeux, J. P. (1996). Neuronal nicotinic receptor alpha 6 subunit mRNA is selectively concentrated in catecholaminergic nuclei of the rat brain. Eur. J. Neurosci. 8, 2428-2439. doi: 10.1111/j.14609568.1996.tb01206.x

Leonard, S., Gault, J., Hopkins, J., Logel, J., Vianzon, R., Short, M., et al. (2002). Association of promoter variants in the alpha7 nicotinic acetylcholine receptor subunit gene with an inhibitory deficit found in schizophrenia. Arch. Gen. Psychiatry 59, 1085-1096. doi: 10.1001/archpsyc.59.12.1085

Lesser, R. P., Fahn, S., Snider, S. R., Cote, L. J., Isgreen, W. P., and Barrett, R. E. (1979). Analysis of the clinical problems in parkinsonism and the complications of long-term levodopa therapy. Neurology 29, 1253-1260. doi: 10.1212/WNL.29.9_Part_1.1253

Levey, A. I., Kitt, C. A., Simonds, W. F., Price, D. L., and Brann, M. R. (1991). Identification and localization of muscarinic acetylcholine receptor proteins in brain with subtype-specific antibodies. J. Neurosci. 11, 3218-3226.

Li, J.-L., Kaneko, T., and Mizuno, N. (2002). Synaptic association of dopaminergic axon terminals and neurokinin-1 receptor-expressing intrinsic neurons in the striatum of the rat. Neurosci. Lett. 324, 9-12. doi: 10.1016/S03043940(02)00138-6

Lin, J. Y., Chung, K. K. H., de Castro, D., Funk, G. D., and Lipski, J. (2004) Effects of muscarinic acetylcholine receptor activation on membrane currents and intracellular messengers in medium spiny neurones of the rat striatum. Eur. J. Neurosci. 20, 1219-1230. doi: 10.1111/j.1460-9568.2004.03576.x

Linazasoro, G. (1994). Anticholinergics and dyskinesia. Mov. Disord. Off. J. Mov Disord. Soc. 9, 689. doi: 10.1002/mds.870090618

Linden, D. J., Dickinson, M. H., Smeyne, M., and Connor, J. A. (1991). A long-term depression of AMPA currents in cultured cerebellar Purkinje neurons. Neuron 7, 81-89. doi: 10.1016/0896-6273(91)90076-C

Liu, Z., Otsu, Y., Vasuta, C., Nawa, H., and Murphy, T. H. (2007). Action-potentialindependent GABAergic tone mediated by nicotinic stimulation of immature striatal miniature synaptic transmission. J. Neurophysiol. 98, 581-593. doi: 10.1152/jn.00768.2006

Luo, R., Janssen, M. J., Partridge, J. G., and Vicini, S. (2013). Direct and GABAmediated indirect effects of nicotinic ACh receptor agonists on striatal neurones. J. Physiol. 591, 203-217. doi: 10.1113/jphysiol.2012.241786

MacDermott, A. B., Role, L. W., and Siegelbaum, S. A. (1999). Presynaptic ionotropic receptors and the control of transmitter release. Annu. Rev. Neurosci. 22, 443-485. doi: 10.1146/annurev.neuro.22.1.443

Macintosh, F. C. (1941). The distribution of acetylcholine in the peripheral and the central nervous system. J. Physiol. 99, 436-442.

Mahon, S., Deniau, J.-M., and Charpier, S. (2004). Corticostriatal plasticity: life after the depression. Trends Neurosci. 27, 460-467. doi: 10.1016/j.tins.2004.06.010

Malenka, R. C., and Kocsis, J. D. (1988). Presynaptic actions of carbachol and adenosine on corticostriatal synaptic transmission studied in vitro. J. Neurosci. 8, 3750-3756.

Mansour, A., Fox, C. A., Burke, S., Meng, F., Thompson, R. C., Akil, H., et al. (1994). Mu, delta, and kappa opioid receptor mRNA expression in the rat CNS: an in situ hybridization study. J. Comp. Neurol. 350, 412-438. doi: $10.1002 /$ cne. 903500307

Manyam, B. V. (1990). Paralysis agitans and levodopa in "Ayurveda": ancient Indian medical treatise. Mov. Disord. Off. J. Mov. Disord. Soc. 5, 47-48. doi: $10.1002 / \mathrm{mds} .870050112$

Manyam, B. V., and Sánchez-Ramos, J. R. (1999). Traditional and complementary therapies in Parkinson's disease. Adv. Neurol. 80, 565-574.

Marchi, M., Risso, F., Viola, C., Cavazzani, P., and Raiteri, M. (2002). Direct evidence that release-stimulating alpha7* nicotinic cholinergic receptors are localized on human and rat brain glutamatergic axon terminals. J. Neurochem. 80, 1071-1078. doi: 10.1046/j.0022-3042.2002.00805.x

Marchi, M., Sanguineti, P., and Raiteri, M. (1990). Muscarinic receptors mediate direct inhibition of GABA release from rat striatal nerve terminals. Neurosci. Lett. 116, 347-351. doi: 10.1016/0304-3940(90)90099-U 
Markram, H., Lübke, J., Frotscher, M., and Sakmann, B. (1997). Regulation of synaptic efficacy by coincidence of postsynaptic APs and EPSPs. Science 275, 213-215. doi: 10.1126/science.275.5297.213

Martella, G., Platania, P., Vita, D., Sciamanna, G., Cuomo, D., Tassone, A., et al. (2009). Enhanced sensitivity to group II mGlu receptor activation at corticostriatal synapses in mice lacking the familial parkinsonism-linked genes PINK1 or Parkin. Exp. Neurol. 215, 388-396. doi: 10.1016/j.expneurol.2008.11.001

Martin-Schild, S., Gerall, A. A., Kastin, A. J., and Zadina, J. E. (1999). Differential distribution of endomorphin 1- and endomorphin 2-like immunoreactivities in the CNS of the rodent. J. Comp. Neurol. 405, 450-471.

Martone, M. E., Armstrong, D. M., Young, S. J., and Groves, P. M. (1992). Ultrastructural examination of enkephalin and substance $P$ input to cholinergic neurons within the rat neostriatum. Brain Res. 594, 253-262. doi: 10.1016/00068993(92)91132-X

Matsubayashi, H., Amano, T., Amano, H., and Sasa, M. (2001). Excitation of rat striatal large neurons by dopamine and/or glutamate released from nerve terminals via presynaptic nicotinic receptor (A4beta2 type) stimulation. Jpn. J. Pharmacol. 86, 429-436. doi: 10.1254/jjp.86.429

Matsuda, W., Furuta, T., Nakamura, K. C., Hioki, H., Fujiyama, F., Arai, R., et al. (2009). Single nigrostriatal dopaminergic neurons form widely spread and highly dense axonal arborizations in the neostriatum. J. Neurosci. 29, 444-453. doi: 10.1523/JNEUROSCI.4029-08.2009

Maurin, Y., Banrezes, B., Menetrey, A., Mailly, P., and Deniau, J. M. (1999) Three-dimensional distribution of nigrostriatal neurons in the rat: relation to the topography of striatonigral projections. Neuroscience 91, 891-909. doi: 10.1016/S0306-4522(98)00681-2

McEvoy, J. P., and Allen, T. B. (2002). The importance of nicotinic acetylcholine receptors in schizophrenia, bipolar disorder and Tourette's syndrome. Curr. Drug Targets CNS Neurol. Disord. 1, 433-442. doi: 10.2174/1568007023339210

McGeer, P. L., and McGeer, E. G. (1977). Possible changes in striatal and limbic cholinergic systems in schizophrenia. Arch. Gen. Psychiatry 34, 1319-1323. doi: 10.1001/archpsyc.1977.01770230061003

McGehee, D. S., Heath, M. J., Gelber, S., Devay, P., and Role, L. W. (1995). Nicotine enhancement of fast excitatory synaptic transmission in CNS by presynaptic receptors. Science 269, 1692-1696. doi: 10.1126/science.7569895

McGehee, D. S., and Role, L. W. (1995). Physiological diversity of nicotinic acetylcholine receptors expressed by vertebrate neurons. Annu. Rev. Physiol. 57, 521-546. doi: 10.1146/annurev.ph.57.030195.002513

Mirenowicz, J., and Schultz, W. (1996). Preferential activation of midbrain dopamine neurons by appetitive rather than aversive stimuli. Nature 379, 449-451. doi: 10.1038/379449a0

Morens, D. M., Grandinetti, A., Reed, D., White, L. R., and Ross, G. W. (1995). Cigarette smoking and protection from Parkinson's disease: false association or etiologic clue? Neurology 45, 1041-1051. doi: 10.1212/WNL.45.6.1041

Mori, F., Tanji, K., Zhang, H., Kakita, A., Takahashi, H., and Wakabayashi, K. (2008). alpha-Synuclein pathology in the neostriatum in Parkinson's disease. Acta Neuropathol. (Berl.) 115, 453-459. doi: 10.1007/s00401-007-0316-4

Moss, J., and Bolam, J. P. (2008). A dopaminergic axon lattice in the striatum and its relationship with cortical and thalamic terminals. J. Neurosci. 28, 11221-11230. doi: 10.1523/JNEUROSCI.2780-08.2008

Mulder, A. H., Burger, D. M., Wardeh, G., Hogenboom, F., and Frankhuyzen, A. L. (1991). Pharmacological profile of various kappa-agonists at kappa-, mu- and delta-opioid receptors mediating presynaptic inhibition of neurotransmitter release in the rat brain. Br. J. Pharmacol. 102, 518-522. doi: 10.1111/j.14765381.1991.tb12203.x

Mulder, A. H., Wardeh, G., Hogenboom, F., and Frankhuyzen, A. L. (1984). Kappaand delta-opioid receptor agonists differentially inhibit striatal dopamine and acetylcholine release. Nature 308, 278-280. doi: 10.1038/308278a0

Mulle, C., Choquet, D., Korn, H., and Changeux, J. P. (1992). Calcium influx through nicotinic receptor in rat central neurons: its relevance to cellular regulation. Neuron 8, 135-143. doi: 10.1016/0896-6273(92)90115-T

Nelson, A. B., Bussert, T. G., Kreitzer, A. C., and Seal, R. P. (2014a). Striatal cholinergic neurotransmission requires VGLUT3. J. Neurosci. 34, 8772-8777. doi: 10.1523/JNEUROSCI.0901-14.2014

Nelson, A. B., Hammack, N., Yang, C. F., Shah, N. M., Seal, R. P., and Kreitzer, A. C. (2014b). Striatal cholinergic interneurons drive GABA release from dopamine terminals. Neuron 82, 63-70. doi: 10.1016/j.neuron.2014.01.023

Nicholas, A. P., Pieribone, V. A., Arvidsson, U., and Hökfelt, T. (1992). Serotonin-, substance P- and glutamate/aspartate-like immunoreactivities in medullo-spinal pathways of rat and primate. Neuroscience 48, 545-559. doi: 10.1016/0306-4522(92)90401-M

Nishiyama, M., Hong, K., Mikoshiba, K., Poo, M. M., and Kato, K. (2000). Calcium stores regulate the polarity and input specificity of synaptic modification. Nature 408, 584-588. doi: 10.1038/35046067

Norgren, R., Hajnal, A., and Mungarndee, S. S. (2006). Gustatory reward and the nucleus accumbens. Physiol. Behav. 89, 531-535. doi: 10.1016/j.physbeh.2006.05.024

Ovallath, S., and Deepa, P. (2013). The history of parkinsonism: descriptions in ancient Indian medical literature. Mov. Disord. Off. J. Mov. Disord. Soc. 28, 566-568. doi: 10.1002/mds.25420

Pakhotin, P., and Bracci, E. (2007). Cholinergic interneurons control the excitatory input to the striatum. J. Neurosci. 27, 391-400. doi: 10.1523/JNEUROSCI.370906.2007

Pancani, T., Bolarinwa, C., Smith, Y., Lindsley, C. W., Conn, P. J., and Xiang, Z. (2014). M4 mAChR-mediated modulation of glutamatergic transmission at corticostriatal synapses. ACS Chem. Neurosci. 5, 318-324. doi: 10.1021/cn500003z

Panula, P., Yang, H. Y., and Costa, E. (1984). Histamine-containing neurons in the rat hypothalamus. Proc. Natl. Acad. Sci. U.S.A. 81, 2572-2576. doi: 10.1073/pnas.81.8.2572

Parkinson, J. (1817). An Essay on the Shaking Palsy. London: Whittingham and Rowland for Sherwood, Needly and Jones.

Parsons, M. E., and Ganellin, C. R. (2006). Histamine and its receptors. Br. J. Pharmacol. 147(Suppl. 1), S127-S135. doi: 10.1038/sj.bjp.0706440

Patrick, J., Séquéla, P., Vernino, S., Amador, M., Luetje, C., and Dani, J. A. (1993). Functional diversity of neuronal nicotinic acetylcholine receptors. Prog. Brain Res. 98, 113-120. doi: 10.1016/S0079-6123(08)62387-0

Pérez-Garci, E., Bargas, J., and Galarraga, E. (2003). The role of Ca2+ channels in the repetitive firing of striatal projection neurons. Neuroreport 14, 1253-1256. doi: 10.1097/01.wnr.0000081861.45938.71

Perez-Rosello, T., Figueroa, A., Salgado, H., Vilchis, C., Tecuapetla, F., Guzman, J. N., et al. (2005). Cholinergic control of firing pattern and neurotransmission in rat neostriatal projection neurons: role of CaV2.1 and CaV2.2 Ca2+ channels. J. Neurophysiol. 93, 2507-2519. doi: 10.1152/jn.00853.2004

Perez, X. A., Ly, J., McIntosh, J. M., and Quik, M. (2012). Long-term nicotine exposure depresses dopamine release in nonhuman primate nucleus accumbens. J. Pharmacol. Exp. Ther. 342, 335-344. doi: 10.1124/jpet.112. 194084

Perez, X. A., McIntosh, J. M., and Quik, M. (2013). Long-term nicotine treatment down-regulates $\alpha 6 \beta 2^{*}$ nicotinic receptor expression and function in nucleus accumbens. J. Neurochem. 127, 762-771. doi: 10.1111/jnc.12442

Perreault, M. L., Fan, T., Alijaniaram, M., O’Dowd, B. F., and George, S. R. (2012). Dopamine D1-D2 receptor heteromer in dual phenotype GABA/glutamate-coexpressing striatal medium spiny neurons: regulation of BDNF, GAD67 and VGLUT1/2. PLoS ONE 7:e33348. doi: 10.1371/journal.pone. 0033348

Persohn, E., Malherbe, P., and Richards, J. G. (1992). Comparative molecular neuroanatomy of cloned GABAA receptor subunits in the rat CNS. J. Comp. Neurol. 326, 193-216. doi: 10.1002/cne.903260204

Picconi, B., Passino, E., Sgobio, C., Bonsi, P., Barone, I., Ghiglieri, V., et al. (2006) Plastic and behavioral abnormalities in experimental Huntington's disease: a crucial role for cholinergic interneurons. Neurobiol. Dis. 22, 143-152. doi: 10.1016/j.nbd.2005.10.009

Piggott, M. A., Owens, J., O’Brien, J., Colloby, S., Fenwick, J., Wyper, D., et al. (2003). Muscarinic receptors in basal ganglia in dementia with Lewy bodies, Parkinson's disease and Alzheimer's disease. J. Chem. Neuroanat. 25, 161-173. doi: 10.1016/S0891-0618(03)00002-4

Pisani, A., Bonsi, P., Catania, M. V., Giuffrida, R., Morari, M., Marti, M., et al. (2002). Metabotropic glutamate 2 receptors modulate synaptic inputs and calcium signals in striatal cholinergic interneurons. J. Neurosci. 22, 6176-6185.

Pisani, A., Bonsi, P., Centonze, D., Bernardi, G., and Calabresi, P. (2001). Functional coexpression of excitatory mGluR1 and mGluR5 on striatal cholinergic interneurons. Neuropharmacology 40, 460-463. doi: 10.1016/S00283908(00)00184-2

Pisani, A., Bonsi, P., Centonze, D., Martorana, A., Fusco, F., Sancesario, G., et al. (2003). Activation of betal-adrenoceptors excites striatal cholinergic interneurons through a cAMP-dependent, protein kinase-independent pathway. J. Neurosci. 23, 5272-5282. 
Plotkin, J. L., Shen, W., Rafalovich, I., Sebel, L. E., Day, M., Chan, C. S., et al. (2013). Regulation of dendritic calcium release in striatal spiny projection neurons. J. Neurophysiol. 110, 2325-2336. doi: 10.1152/jn.004 22.2013

Poewe, W., Wolters, E., Emre, M., Onofri, M., Hsu, C., Tekin, S., et al. (2006). Longterm benefits of rivastigmine in dementia associated with Parkinson's disease: an active treatment extension study. Mov. Disord. Off. J. Mov. Disord. Soc. 21, 456-461. doi: $10.1002 / \mathrm{mds} .20700$

Ponterio, G., Tassone, A., Sciamanna, G., Riahi, E., Vanni, V., Bonsi, P., et al. (2013). Powerful inhibitory action of mu opioid receptors (MOR) on cholinergic interneuron excitability in the dorsal striatum. Neuropharmacology 75, 78-85. doi: 10.1016/j.neuropharm.2013.07.006

Potter, A. S., Dunbar, G., Mazzulla, E., Hosford, D., and Newhouse, P. A. (2014). AZD3480, a novel nicotinic receptor agonist, for the treatment of attentiondeficit/hyperactivity disorder in adults. Biol. Psychiatry 75, 207-214. doi: 10.1016/j.biopsych.2013.06.002

Pourcher, E., Bonnet, A. M., Kefalos, J., Dubois, B., and Agid, Y. (1989). Effects of etybenzatropine and diazepam on levodopa-induced diphasic dyskinesias in Parkinson's disease. Mov. Disord. Off. J. Mov. Disord. Soc. 4, 195-201. doi: $10.1002 / \mathrm{mds} .870040301$

Prast, H., Tran, M. H., Fischer, H., Kraus, M., Lamberti, C., Grass, K., et al. (1999a). Histaminergic neurons modulate acetylcholine release in the ventral striatum: role of H3 histamine receptors. Naunyn. Schmiedebergs Arch. Pharmacol. 360, 558-564. doi: 10.1007/s002109900097

Prast, H., Tran, M. H., Lamberti, C., Fischer, H., Kraus, M., Grass, K., et al. (1999b). Histaminergic neurons modulate acetylcholine release in the ventral striatum: role of $\mathrm{H} 1$ and $\mathrm{H} 2$ histamine receptors. Naunyn. Schmiedebergs Arch. Pharmacol. 360, 552-557. doi: 10.1007/s002109900098

Preston, Z., Lee, K., Widdowson, L., Richardson, P. J., and Pinnock, R. D. (2000). Tachykinins increase $[3 \mathrm{H}]$ acetylcholine release in mouse striatum through multiple receptor subtypes. Neuroscience 95, 367-376. doi: 10.1016/S03064522(99)00440-6

Puttfarcken, P. S., Jacobs, I., and Faltynek, C. R. (2000). Characterization of nicotinic acetylcholine receptor-mediated $[(3) \mathrm{H}]$-dopamine release from rat cortex and striatum. Neuropharmacology 39, 2673-2680. doi: 10.1016/S00283908(00)00131-3

Quik, M., Bordia, T., and O'Leary, K. (2007). Nicotinic receptors as CNS targets for Parkinson's disease. Biochem. Pharmacol. 74, 1224-1234. doi: 10.1016/j.bcp.2007.06.015

Quik, M., and McIntosh, J. M. (2006). Striatal alpha6* nicotinic acetylcholine receptors: potential targets for Parkinson's disease therapy. J. Pharmacol. Exp. Ther. 316, 481-489. doi: 10.1124/jpet.105.094375

Quik, M., Perez, X. A., and Bordia, T. (2012). Nicotine as a potential neuroprotective agent for Parkinson's disease. Mov. Disord. Off. J. Mov. Disord. Soc. 27, 947-957. doi: 10.1002/mds.25028

Quik, M., Sum, J. D., Whiteaker, P., McCallum, S. E., Marks, M. J., Musachio, J., et al. (2003). Differential declines in striatal nicotinic receptor subtype function after nigrostriatal damage in mice. Mol. Pharmacol. 63, 1169-1179. doi: 10.1124/mol.63.5.1169

Quik, M., and Wonnacott, S. (2011). $\alpha 6 \beta 2^{\star}$ and $\alpha 4 \beta 2^{\star}$ nicotinic acetylcholine receptors as drug targets for Parkinson's disease. Pharmacol. Rev. 63, 938-966. doi: 10.1124/pr.110.003269

Radek, R. J., Kohlhaas, K. L., Rueter, L. E., and Mohler, E. G. (2010). Treating the cognitive deficits of schizophrenia with alpha4beta2 neuronal nicotinic receptor agonists. Curr. Pharm. Des. 16, 309-322. doi: 10.2174/138161210790 170166

Raedler, T. J., Knable, M. B., Jones, D. W., Urbina, R. A., Gorey, J. G., Lee, K. S., et al. (2003). In vivo determination of muscarinic acetylcholine receptor availability in schizophrenia. Am. J. Psychiatry 160, 118-127. doi: 10.1176/appi.ajp.160.1.118

Ragozzino, M. E. (2003). Acetylcholine actions in the dorsomedial striatum support the flexible shifting of response patterns. Neurobiol. Learn. Mem. 80, 257-267. doi: 10.1016/S1074-7427(03)00077-7

Raudino, F. (2012). The parkinson disease before james parkinson. Neurol. Sci. Off. J. Ital. Neurol. Soc. Ital. Soc. Clin. Neurophysiol. 33, 945-948. doi: 10.1007/s10072-011-0816-9

Ravel, S., Legallet, E., and Apicella, P. (1999). Tonically active neurons in the monkey striatum do not preferentially respond to appetitive stimuli. Exp. Brain Res. 128, 531-534. doi: $10.1007 / \mathrm{s} 002210050876$
Reynolds, J. N. J., Hyland, B. I., and Wickens, J. R. (2004). Modulation of an afterhyperpolarization by the substantia nigra induces pauses in the tonic firing of striatal cholinergic interneurons. J. Neurosci. 24, 9870-9877. doi: 10.1523/JNEUROSCI.3225-04.2004

Rezvani, A. H., Cauley, M. C., Johnson, E. C., Gatto, G. J., and Levin, E. D. (2012). Effects of AZD3480, a neuronal nicotinic acetylcholine receptor agonist, and donepezil on dizocilpine-induced attentional impairment in rats. Psychopharmacology (Berl.) 223, 251-258. doi: 10.1007/s00213-012-2712-2

Rice, M. E., and Cragg, S. J. (2004). Nicotine amplifies reward-related dopamine signals in striatum. Nat. Neurosci. 7, 583-584. doi: 10.1038/nn1244

Richardson, P. J., Dixon, A. K., Lee, K., Bell, M. I., Cox, P. J., Williams, R., et al. (2000). Correlating physiology with gene expression in striatal cholinergic neurones. J. Neurochem. 74, 839-846. doi: 10.1046/j.1471-4159.2000. 740839.x

Rinne, J. O., Laihinen, A., Lönnberg, P., Marjamäki, P., and Rinne, U. K. (1991). A post-mortem study on striatal dopamine receptors in Parkinson's disease. Brain Res. 556, 117-122. doi: 10.1016/0006-8993(91)90554-9

Robinson, T. E., and Berridge, K. C. (2000). The psychology and neurobiology of addiction: an incentive-sensitization view. Addict. Abingdon Engl. 95(Suppl. 2), S91-S117. doi: 10.1080/09652140050111681

Rodríguez, M., and González-Hernández, T. (1999). Electrophysiological and morphological evidence for a GABAergic nigrostriatal pathway. J. Neurosci. 19, 4682-4694.

Rodríguez-Pallares, J., Labandeira-García, J. L., Muñoz, A., and Caruncho, H. J. (2000). Morphology and neurochemistry of two striatal neuronal subtypes expressing the GABA(A) receptor alpha3-subunit in the rat. Brain Res. 876, 124-130. doi: 10.1016/S0006-8993(00)02636-6

Rojas, A., and Dingledine, R. (2013). Ionotropic glutamate receptors: regulation by G-protein-coupled receptors. Mol. Pharmacol. 83, 746-752. doi: 10.1124/mol.112.083352

Sanberg, P. R., Shytle, R. D., and Silver, A. A. (1998). Treatment of Tourette's syndrome with mecamylamine. Lancet 352, 705-706. doi: 10.1016/S01406736(05)60822-7

Sandor, N. T., Zelles, T., Kiss, J., Sershen, H., Torocsik, A., Lajtha, A., et al. (1991). Effect of nicotine on dopaminergic-cholinergic interaction in the striatum. Brain Res. 567, 313-316. doi: 10.1016/0006-8993(91)90810-I

Santangelo, G., Barone, P., Trojano, L., and Vitale, C. (2013a). Pathological gambling in Parkinson's disease. A comprehensive review. Parkinsonism Relat. Disord. 19, 645-653. doi: 10.1016/j.parkreldis.2013.02.007

Santangelo, G., Trojano, L., Barone, P., Errico, D., Grossi, D., and Vitale, C. (2013b). Apathy in Parkinson's disease: diagnosis, neuropsychological correlates, pathophysiology and treatment. Behav. Neurol. 27, 501-513. doi: 10.3233/BEN129025

Sato, A., Sasaoka, T., Nishijo, T., and Momiyama, T. (2014). GABAergic synaptic transmission onto striatal cholinergic interneurons in dopamine D2 receptor knock-out mice. Neuroscience 263, 138-147. doi: 10.1016/j.neuroscience.2014.01.010

Scheibler, P., Pesic, M., Franke, H., Reinhardt, R., Wirkner, K., Illes, P., et al. (2004). P2X2 and P2Y1 immunofluorescence in rat neostriatal mediumspiny projection neurones and cholinergic interneurones is not linked to respective purinergic receptor function. Br. J. Pharmacol. 143, 119-131. doi: 10.1038/sj.bjp.0705916

Schoffelmeer, A. N., Hogenboom, F., and Mulder, A. H. (1997). Kappa1- and kappa2-opioid receptors mediating presynaptic inhibition of dopamine and acetylcholine release in rat neostriatum. Br. J. Pharmacol. 122, 520-524. doi: 10.1038/sj.bjp.0701394

Schwartz, J. C., Arrang, J. M., Garbarg, M., and Korner, M. (1986). Properties and roles of the three subclasses of histamine receptors in brain. J. Exp. Biol. 124, 203-224.

Sharples, C. G., Kaiser, S., Soliakov, L., Marks, M. J., Collins, A. C., Washburn, M., et al. (2000). UB-165: a novel nicotinic agonist with subtype selectivity implicates the alpha4beta2* subtype in the modulation of dopamine release from rat striatal synaptosomes. J. Neurosci. 20, 2783-2791.

Shen, W., Hamilton, S. E., Nathanson, N. M., and Surmeier, D. J. (2005). Cholinergic suppression of KCNQ channel currents enhances excitability of striatal medium spiny neurons. J. Neurosci. 25, 7449-7458. doi: 10.1523/JNEUROSCI.1381-05.2005

Shiflett, M. W., Brown, R. A., and Balleine, B. W. (2010). Acquisition and performance of goal-directed instrumental actions depends on ERK signaling in 
distinct regions of dorsal striatum in rats. J. Neurosci. 30, 2951-2959. doi: 10.1523/JNEUROSCI.1778-09.2010

Shimohama, S., Taniguchi, T., Fujiwara, M., and Kameyama, M. (1985). Biochemical characterization of the nicotinic cholinergic receptors in human brain: binding of (-)-[3H]nicotine. J. Neurochem. 45, 604-610. doi: 10.1111/j.1471-4159.1985.tb04029.x

Shytle, R. D., Silver, A. A., Philipp, M. K., McConville, B. J., and Sanberg, P. R. (1996). Transdermal nicotine for Tourette's syndrome. Drug Dev. Res. 38, 290-298. doi: 10.1002/(SICI) 1098-2299(199607/08)38:3/4<290::AIDDDR18>3.0.CO;2-2

Silver, A. A., Shytle, R. D., and Sanberg, P. R. (2000). Mecamylamine in Tourette's syndrome: a two-year retrospective case study. J. Child Adolesc. Psychopharmacol. 10, 59-68. doi: 10.1089/cap.2000.10.59

Simón-Sánchez, J., Schulte, C., Bras, J. M., Sharma, M., Gibbs, J. R., Berg, D., et al. (2009). Genome-wide association study reveals genetic risk underlying Parkinson's disease. Nat. Genet. 41, 1308-1312. doi: 10.1038/ng.487

Sirviö, J., Rinne, J. O., Valjakka, A., Rinne, U. K., Riekkinen, P. J., and Paljärvi, L. (1989). Different forms of brain acetylcholinesterase and muscarinic binding in Parkinson's disease. J. Neurol. Sci. 90, 23-32. doi: 10.1016/0022-510X(89) 90042-7

Smiley, J. F., Levey, A. I., and Mesulam, M. M. (1999). m2 muscarinic receptor immunolocalization in cholinergic cells of the monkey basal forebrain and striatum. Neuroscience 90, 803-814. doi: 10.1016/S0306-4522(98)00527-2

Smith, R., Chung, H., Rundquist, S., Maat-Schieman, M. L. C., Colgan, L., Englund, E., et al. (2006). Cholinergic neuronal defect without cell loss in Huntington's disease. Hum. Mol. Genet. 15, 3119-3131. doi: 10.1093/hmg/ddl252

Smith, Y., and Kieval, J. Z. (2000). Anatomy of the dopamine system in the basal ganglia. Trends Neurosci. 23, S28-S33. doi: 10.1016/S1471-1931(00)00023-9

Smolders, I., Bogaert, L., Ebinger, G., and Michotte, Y. (1997). Muscarinic modulation of striatal dopamine, glutamate, and GABA release, as measured with in vivo microdialysis. J. Neurochem. 68, 1942-1948. doi: 10.1046/j.14714159.1997.68051942.x

Sprouse, J. S., Bradberry, C. W., Roth, R. H., and Aghajanian, G. K. (1989). MDMA (3,4-methylenedioxymethamphetamine) inhibits the firing of dorsal raphe neurons in brain slices via release of serotonin. Eur. J. Pharmacol. 167, 375-383. doi: 10.1016/0014-2999(89)90446-9

Standaert, D. G., Friberg, I. K., Landwehrmeyer, G. B., Young, A. B., and Penney, J. B. Jr. (1999). Expression of NMDA glutamate receptor subunit mRNAs in neurochemically identified projection and interneurons in the striatum of the rat. Brain Res. Mol. Brain Res. 64, 11-23. doi: 10.1016/S0169-328X(98)00293-9

Stephenson-Jones, M., Samuelsson, E., Ericsson, J., Robertson, B., and Grillner, S. (2011). Evolutionary conservation of the basal ganglia as a common vertebrate mechanism for action selection. Curr. Biol. 21, 1081-1091. doi: 10.1016/j.cub.2011.05.001

Straub, C., Tritsch, N. X., Hagan, N. A., Gu, C., and Sabatini, B. L. (2014), Multiphasic modulation of cholinergic interneurons by nigrostriatal afferents. J. Neurosci. 34, 8557-8569. doi: 10.1523/JNEUROSCI.0589-14.2014

Stuber, G. D., Hnasko, T. S., Britt, J. P., Edwards, R. H., and Bonci, A. (2010). Dopaminergic terminals in the nucleus accumbens but not the dorsal striatum corelease glutamate. J. Neurosci. 30, 8229-8233. doi: 10.1523/JNEUROSCI.1754-10.2010

Sugita, S., Uchimura, N., Jiang, Z. G., and North, R. A. (1991). Distinct muscarinic receptors inhibit release of gamma-aminobutyric acid and excitatory amino acids in mammalian brain. Proc. Natl. Acad. Sci. U.S.A. 88, 2608-2611. doi: 10.1073/pnas.88.6.2608

Sullivan, M. A., Chen, H., and Morikawa, H. (2008). Recurrent inhibitory network among striatal cholinergic interneurons. J. Neurosci. 28, 8682-8690. doi: 10.1523/JNEUROSCI.2411-08.2008

Surmeier, D. J., Ding, J., Day, M., Wang, Z., and Shen, W. (2007). D1 and D2 dopamine-receptor modulation of striatal glutamatergic signaling in striatal medium spiny neurons. Trends Neurosci. 30, 228-235. doi: 10.1016/j.tins.2007.03.008

Suzuki, M., Desmond, T. J., Albin, R. L., and Frey, K. A. (2001a). Vesicular neurotransmitter transporters in Huntington's disease: initial observations and comparison with traditional synaptic markers. Synapse 41, 329-336. doi: 10.1002/syn.1089

Suzuki, T., Miura, M., Nishimura, K., and Aosaki, T. (2001b). Dopaminedependent synaptic plasticity in the striatal cholinergic interneurons. J. Neurosci. 21, 6492-6501.
Szydlowski, S. N., Pollak Dorocic, I., Planert, H., Carlén, M., Meletis, K., and Silberberg, G. (2013). Target selectivity of feedforward inhibition by striatal fast-spiking interneurons. J. Neurosci. 33, 1678-1683. doi: 10.1523/JNEUROSCI.3572-12.2013

Tallaksen-Greene, S. J., Kaatz, K. W., Romano, C., and Albin, R. L. (1998), Localization of mGluR1a-like immunoreactivity and mGluR5-like immunoreactivity in identified populations of striatal neurons. Brain Res. 780, 210-217. doi: 10.1016/S0006-8993(97)01141-4

Tashiro, Y., Sugimoto, T., Hattori, T., Uemura, Y., Nagatsu, I., Kikuchi, H., et al. (1989). Tyrosine hydroxylase-like immunoreactive neurons in the striatum of the rat. Neurosci. Lett. 97, 6-10. doi: 10.1016/0304-3940(89)90130-4

Tepper, J. M., Tecuapetla, F., Koós, T., and Ibáñez-Sandoval, O. (2010). Heterogeneity and diversity of striatal GABAergic interneurons. Front. Neuroanat. 4:150. doi: 10.3389/fnana.2010.00150

Testa, C. M., Standaert, D. G., Young, A. B., and Penney, J. B. Jr. (1994). Metabotropic glutamate receptor mRNA expression in the basal ganglia of the rat. J. Neurosci. 14, 3005-3018.

Thomas, T. M., Smith, Y., Levey, A. I., and Hersch, S. M. (2000). Cortical inputs to $\mathrm{m} 2$-immunoreactive striatal interneurons in rat and monkey. Synapse 37, 252-261. doi: 10.1002/1098-2396(20000915)37:4<252::AID-SYN2>3.0. $\mathrm{CO} ; 2-\mathrm{A}$

Threlfell, S., Clements, M. A., Khodai, T., Pienaar, I. S., Exley, R., Wess, J., et al. (2010). Striatal muscarinic receptors promote activity dependence of dopamine transmission via distinct receptor subtypes on cholinergic interneurons in ventral versus dorsal striatum. J. Neurosci. 30, 3398-3408. doi: 10.1523/JNEUROSCI.5620-09.2010

Threlfell, S., and Cragg, S. J. (2011). Dopamine signaling in dorsal versus ventral striatum: the dynamic role of cholinergic interneurons. Front. Syst. Neurosci. 5:11. doi: $10.3389 /$ fnsys.2011.00011

Threlfell, S., Lalic, T., Platt, N. J., Jennings, K. A., Deisseroth, K., and Cragg, S. J. (2012). Striatal dopamine release is triggered by synchronized activity in cholinergic interneurons. Neuron 75, 58-64. doi: 10.1016/j.neuron.2012.04.038

Tian, Y., Gunther, J. R., Liao, I. H., Liu, D., Ander, B. P., Stamova, B. S., et al. (2011). GABA- and acetylcholine-related gene expression in blood correlate with tic severity and microarray evidence for alternative splicing in Tourette syndrome: a pilot study. Brain Res. 1381, 228-236. doi: 10.1016/j.brainres.2011.01.026

Timmerman, H. (1989). Histamine receptors in the central nervous system. Pharm. Weekbl. Sci. 11, 146-150. doi: 10.1007/BF01959461

Todd, R. D., Lobos, E. A., Sun, L.-W., and Neuman, R. J. (2003). Mutational analysis of the nicotinic acetylcholine receptor alpha 4 subunit gene in attention deficit/hyperactivity disorder: evidence for association of an intronic polymorphism with attention problems. Mol. Psychiatry 8, 103-108. doi: 10.1038/sj.mp. 4001257

Tritsch, N. X., Ding, J. B., and Sabatini, B. L. (2012). Dopaminergic neurons inhibit striatal output through non-canonical release of GABA. Nature 490, 262-266. doi: 10.1038/nature11466

Tso, P. H., and Wong, Y. H. (2003). Molecular basis of opioid dependence: role of signal regulation by G-proteins. Clin. Exp. Pharmacol. Physiol. 30, 307-316. doi: 10.1046/j.1440-1681.2003.03835.x

Vilaró, M. T., Palacios, J. M., and Mengod, G. (1990). Localization of m5 muscarinic receptor mRNA in rat brain examined by in situ hybridization histochemistry. Neurosci. Lett. 114, 154-159. doi: 10.1016/0304-3940(90)90064-G

Voon, V., Fernagut, P.-O., Wickens, J., Baunez, C., Rodriguez, M., Pavon, N., et al. (2009). Chronic dopaminergic stimulation in Parkinson's disease: from dyskinesias to impulse control disorders. Lancet Neurol. 8, 1140-1149. doi: 10.1016/S1474-4422(09)70287-X

Voorn, P., Vanderschuren, L. J. M. J., Groenewegen, H. J., Robbins, T. W., and Pennartz, C. M. A. (2004). Putting a spin on the dorsal-ventral divide of the striatum. Trends Neurosci. 27, 468-474. doi: 10.1016/j.tins.2004.06.006

Vorobjev, V. S., Sharonova, I. N., Haas, H. L., and Sergeeva, O. A. (2000). Differential modulation of AMPA receptors by cyclothiazide in two types of striatal neurons. Eur. J. Neurosci. 12, 2871-2880. doi: 10.1046/j.14609568.2000.00175.x

Vuillet, J., Dimova, R., Nieoullon, A., and Kerkerian-Le Goff, L. (1992). Ultrastructural relationships between choline acetyltransferase- and neuropeptide y-containing neurons in the rat striatum. Neuroscience 46, 351-360. doi: 10.1016/0306-4522(92)90057-9

Wallis, D., Arcos-Burgos, M., Jain, M., Castellanos, F. X., Palacio, J. D., Pineda, D., et al. (2009). Polymorphisms in the neural nicotinic acetylcholine receptor $\alpha 4$ 
subunit (CHRNA4) are associated with ADHD in a genetic isolate. Atten. Deficit Hyperact. Disord. 1, 19-24. doi: 10.1007/s12402-009-0003-5

Wan, J., and Poo, M. (1999). Activity-induced potentiation of developing neuromuscular synapses. Science 285, 1725-1728. doi: 10.1126/science.285.5434.1725

Watanabe, K., and Kimura, M. (1998). Dopamine receptor-mediated mechanisms involved in the expression of learned activity of primate striatal neurons. J. Neurophysiol. 79, 2568-2580.

Weiner, D. M., Levey, A. I., and Brann, M. R. (1990). Expression of muscarinic acetylcholine and dopamine receptor mRNAs in rat basal ganglia. Proc. Natl. Acad. Sci. U.S.A. 87, 7050-7054. doi: 10.1073/pnas.87.18.7050

Wess, J. (1996). Molecular biology of muscarinic acetylcholine receptors. Crit. Rev. Neurobiol. 10, 69-99. doi: 10.1615/CritRevNeurobiol.v10.i1.40

West, A. B., Cowell, R. M., Daher, J. P. L., Moehle, M. S., Hinkle, K. M., Melrose, H. L., et al. (2014). Differential LRRK2 expression in the cortex, striatum, and substantia nigra in transgenic and nontransgenic rodents. J. Comp. Neurol. 522, 2465-2480. doi: 10.1002/cne.23583

Whyte, R. K., Hunter, K. R., Laurence, D. R., Stern, G. M., and Armitage, P. (1971). Levodopa and orphenadrine hydrochloride in Parkinsonism. Eur. J. Clin. Pharmacol. 4, 18-21. doi: 10.1007/BF00568893

Wilens, T. E., and Decker, M. W. (2007). Neuronal nicotinic receptor agonists for the treatment of attention-deficit/hyperactivity disorder: focus on cognition. Biochem. Pharmacol. 74, 1212-1223. doi: 10.1016/j.bcp.2007.07.002

Wilson, C. J., Chang, H. T., and Kitai, S. T. (1990). Firing patterns and synaptic potentials of identified giant aspiny interneurons in the rat neostriatum. J. Neurosci. 10, 508-519.

Wilson, C. J., and Groves, P. M. (1981). Spontaneous firing patterns of identified spiny neurons in the rat neostriatum. Brain Res. 220, 67-80. doi: 10.1016/00068993(81)90211-0

Won, L., Ding, Y., Singh, P., and Kang, U. J. (2014). Striatal cholinergic cell ablation attenuates L-DOPA induced dyskinesia in Parkinsonian mice. J. Neurosci. 34, 3090-3094. doi: 10.1523/JNEUROSCI.2888-13.2014

Wonnacott, S., Kaiser, S., Mogg, A., Soliakov, L., and Jones, I. W. (2000). Presynaptic nicotinic receptors modulating dopamine release in the rat striatum. Eur. $J$. Pharmacol. 393, 51-58. doi: 10.1016/S0014-2999(00)00005-4

Woolf, N. J., and Butcher, L. L. (1981). Cholinergic neurons in the caudateputamen complex proper are intrinsically organized: a combined Evans blue and acetylcholinesterase analysis. Brain Res. Bull. 7, 487-507. doi: 10.1016/03619230(81)90004-6

Woolf, N. J., Eckenstein, F., and Butcher, L. L. (1984). Cholinergic systems in the rat brain: I. projections to the limbic telencephalon. Brain Res. Bull. 13, 751-784. doi: 10.1016/0361-9230(84)90236-3

Wu, J. C. F., Chruscinski, A., De Jesus Perez, V. A., Singh, H., Pitsiouni, M., Rabinovitch, M., et al. (2009). Cholinergic modulation of angiogenesis: role of the 7 nicotinic acetylcholine receptor. J. Cell. Biochem. 108, 433-446. doi: $10.1002 /$ jcb. 22270

Xiao, C., Nashmi, R., McKinney, S., Cai, H., McIntosh, J. M., and Lester, H. A. (2009). Chronic nicotine selectively enhances alpha4beta $2^{\star}$ nicotinic acetylcholine receptors in the nigrostriatal dopamine pathway. J. Neurosci. 29, 12428-12439. doi: 10.1523/JNEUROSCI.2939-09.2009

Yan, Z., Flores-Hernandez, J., and Surmeier, D. J. (2001). Coordinated expression of muscarinic receptor messenger RNAs in striatal medium spiny neurons. Neuroscience 103, 1017-1024. doi: 10.1016/S0306-4522(01)00039-2
Yan, Z., Song, W. J., and Surmeier, J. (1997). D2 dopamine receptors reduce $\mathrm{N}$-type $\mathrm{Ca} 2+$ currents in rat neostriatal cholinergic interneurons through a membrane-delimited, protein-kinase-C-insensitive pathway. J. Neurophysiol. 77, 1003-1015.

Yasuda, R. P., Ciesla, W., Flores, L. R., Wall, S. J., Li, M., Satkus, S. A., et al. (1993). Development of antisera selective for $\mathrm{m} 4$ and $\mathrm{m} 5$ muscarinic cholinergic receptors: distribution of $\mathrm{m} 4$ and $\mathrm{m} 5$ receptors in rat brain. Mol. Pharmacol. 43, 149-157.

Yin, H. H. (2010). The sensorimotor striatum is necessary for serial order learning. J. Neurosci. 30, 14719-14723. doi: 10.1523/JNEUROSCI.398910.2010

Zhang, D., Mallela, A., Sohn, D., Carroll, F. I., Bencherif, M., Letchworth, S., et al. (2013). Nicotinic receptor agonists reduce L-DOPA-induced dyskinesias in a monkey model of Parkinson's disease. J. Pharmacol. Exp. Ther. 347, 225-234. doi: 10.1124/jpet.113.207639

Zhang, H., and Sulzer, D. (2004). Frequency-dependent modulation of dopamine release by nicotine. Nat. Neurosci. 7, 581-582. doi: 10.1038/nn1243

Zhang, W., Yamada, M., Gomeza, J., Basile, A. S., and Wess, J. (2002). Multiple muscarinic acetylcholine receptor subtypes modulate striatal dopamine release, as studied with M1-M5 muscarinic receptor knock-out mice. J. Neurosci. 22, 6347-6352.

Zhang, Z.-X., Dong, Z.-H., and Román, G. C. (2006). Early descriptions of Parkinson disease in ancient China. Arch. Neurol. 63, 782-784. doi: 10.1001/archneur.63.5.782

Zhou, F. M., Liang, Y., and Dani, J. A. (2001). Endogenous nicotinic cholinergic activity regulates dopamine release in the striatum. Nat. Neurosci. 4, 1224-1229. doi: $10.1038 / \mathrm{nn} 769$

Zhou, F.-W., Xu, J.-J., Zhao, Y., LeDoux, M. S., and Zhou, F.-M. (2006). Opposite functions of histamine $\mathrm{H} 1$ and $\mathrm{H} 2$ receptors and $\mathrm{H} 3$ receptor in substantia nigra pars reticulata. J. Neurophysiol. 96, 1581-1591. doi: 10.1152/jn. 00148.2006

Zugno, A. I., Julião, R. F., Budni, J., Volpato, A. M., Fraga, D. B., Pacheco, F. D., et al. (2013). Rivastigmine reverses cognitive deficit and acetylcholinesterase activity induced by ketamine in an animal model of schizophrenia. Metab. Brain Dis. 28, 501-508 doi: 10.1007/s11011-013-9417-z

Conflict of Interest Statement: The authors declare that the research was conducted in the absence of any commercial or financial relationships that could be construed as a potential conflict of interest.

Received: 17 July 2014; accepted: 05 September 2014; published online: 21 October 2014

Citation: Lim SAO, Kang UJ and McGehee DS (2014) Striatal cholinergic interneuron regulation and circuit effects. Front. Synaptic Neurosci. 6:22. doi: 10.3389/fnsyn. 2014.00022

This article was submitted to the journal Frontiers in Synaptic Neuroscience.

Copyright (c) 2014 Lim, Kang and McGehee. This is an open-access article distributed under the terms of the Creative Commons Attribution License (CC BY). The use, distribution or reproduction in other forums is permitted, provided the original author(s) or licensor are credited and that the original publication in this journal is cited, in accordance with accepted academic practice. No use, distribution or reproduction is permitted which does not comply with these terms. 